\title{
The Proposed Deregulation of Domestic Common Carrier Telecommunications
}

Government regulation of business in this country has experienced great variations in popularity over the years, with the recent history being marked by a clear trend toward deregulation. The desire of legislators to promote competitive markets has led to deregulation in the transportation industry, and the attention of many legislators lately has been focused on the telephone industry as another likely target.

Meanwhile, through a series of soinetimes conflicting decisions between 1959 and 1980, the Federal Communications Commission (FCC) and the federal courts have introduced competition into the telephone industry. The most sweeping of these decisions was the FCC's Second Computer Inquiry ${ }^{1}$ decision, precipitated by the growing confluence of the computer and telecommunications industries. Recent developments in computers and data processing have produced a variety of communications needs that carmot be met by ordinary voice telephone systems. In response, the telecommunications industry has developed a range of sophisticated service offerings that are tailored to the needs of the computer industry and often combine data processing capability and communications services. Acting under the broad statutory mandate given it by the Communications Act of $1934,{ }^{2}$ the FCC sought to determine whether the new specialized services should be regulated and what role common carriers should play in their provision. The Commission drew a distimction between "basic" telephone services, ${ }^{3}$ which offer only pure transmission capability to eustorners, and "enhanced" services, which store the information being transmitted or alter it im content or form. ${ }^{4}$ An example of an enhanced service would be one that offers voice or data storage and retrieval, or changes encoded data froin one code to another. ${ }^{5}$ The Commission decided to

1. Amendment of Section 64.702 of the Commission's Rules and Regulations (Second Computer Inquiry), 77 F.C.C.2d 384 (1980) [hereinafter cited without cross-reference as Second Computer Inquiry].

2. 47 U.S.C. $\S \S 151-609$ (1976).

3. 77 F.C.C. $2 \mathrm{~d}$ at $385-86$.

4. The essential characteristic of a basic telephone service is that it be "transparent" to the imformation being transmitted. Id. at 420 . The nature of the information carried is not determinative; if a carrier transmits digital data processing signals generated by a customer without encoding or modifying the signals, it is providing a basic service.

5. Id. at 420 n. 33; see note 62 and accompanying text infra. 
continue to regulate basic services, but to deregulate enhanced services because "the absence of traditional public utility regulation of enhanced services offers the greatest potential for efficient utilization and full exploitation of the interstate telecommunications network." ${ }^{\text {How- }}$ ever, the FCC required the two largest telephone companies, American Telephone \& Telegrapli Co. (AT\&T) and General Telephone and Electronics Corp. (GTE), to create separate subsidiaries by Marcli 1, 1982 in order to participate in the unregulated portion of the industry.

In addition to these developments in specialized services, competition has arisen in the provision of ordinary long distance voice service in many inarkets. ${ }^{8}$ The Commission recently initiated an inquiry into the desirability of eliminating as far as possible the regulation of rates charged by nondominant carriers operating in competitive markets, relying instead on inarket forces to ensure reasonable rates. ${ }^{9}$ A further development that may lead to increased competition in the industry is the antitrust suit against AT\&T, ${ }^{10}$ through which the Justice Department seeks to divest the telecommunications giant of Western Electric, the AT\&T Long Lines Division, and the Bell operating companies.

These developments, lowever, do not eliminate the need for new legislation concerning common carrier telecommunications activities. Members of Congress, FCC officials, and industry representatives have stated that the Second Computer Inquiry decision needs legislative support. ${ }^{11}$ For a number of reasons, Congress should not hesitate to act.

First, the FCC is currently reconsidering the Second Computer In-

6. 77 F.C.C.2d at 387.

7. Id. at $470-88$. The separate subsidiaries would maintain separate accounting systems, different officers, and separate operating, marketing, installation, and maintenance personnel. They would have to procure their transmission needs from a counmon carrier pursuant to tariff, and could not share computer facilities with an affiliate. They would also have to conduct equipinent leasing or purchasing from such related companies on an arm's length basis, and any research or development performed by a related company for the subsidiary would have to be done on a full-reimbursement basis. Terms for the transfer of money, personnel, or anything else of value between the subsidiary and a related company would have to be written and filed with the Commission. If the parent were to disclose proprietary information and information concerning network design, network changes, or technical standards to the subsidiary, it would also have to disclose the information publicly. The Commission would have to approve the capitalization of the subsidiary. Id. at $498-99$.

8. See Fraser, An Industry That Bears Watching, U.S. News AND WORLD Report, Mar. 5, 1979, at 75 .

9. Policy and Rules Concerning Rates for Competitive Common Carrier Services and Facilities Authorization, 77 F.C.C.2d 308 (1980) [hereinafter cited without cross-reference as Competitive Carrier Rulennaking].

10. United States v. AT\&T, No. 74-1698 (D.D.C., filed Nov. 20, 1974). For a summary of the government's allegations, see Addendum B of the FCC's anicus curiae brief, in Satellite Business Systems, 62 F.C.C.2d 997, 1128-30 (1977).

11. FCC Acts to Deregulate Telecommunications, 38 Cong. Q. WeEkLY Rep. 993, 993-94 (Apr. 12, 1980). 
quiry dccision, and appellate review will almost certainly follow. ${ }^{12}$ The decision may be vulnerable to attack: The Commission's authority to act as a deregulator rather than as a regulator is questionable ${ }^{13}$ and its decision to permit AT\&T to enter the enhanced services market turned on a very narrow reading of the consent decree under which AT\&T is restricted to providing "common carrier communications services." 14 Furthermore, strategies such as the Justice Department suit and the Competitive Carrier procedure, while promising, may be ineffective in promotimg competition in the industry. Even if they ultimately produce satisfactory results, those results may not be finalized for years. ${ }^{15}$

Also, there may be a need for more sweeping reform of the telecommunications industry than the current nonlegislative actions could provide. For example, the legislative proposals that have been advanced for deregulation of the telecommunications industry have been broader than the intended scope of the Competitive Carrier proceeding, simce they would release dommant as well as nondominant carriers from rate regulation procedures in compctitive markets. ${ }^{16}$ This is consistent with the view that technological advances have altered the nature of the industry in such a fundanental way that a broad revision of current regulatory policies and procedures is now appropriate. ${ }^{17}$

Ultimately, perhaps the most important reason to enact legislation in the telecommunications area is to express clearly the policies favored by Congress. ${ }^{18}$ Adopting statutory language stating that competition is

12. Id. at 994. See also H.R. REP. No. 1252, Part 1, 96th Cong., 2d Sess. 46-47 (1980). Thus, much of the present law on these issues may change in the near future.

13. See Second Computer Inquiry, 77 F.C.C.2d at 409 . The courts have stated that although the FCC has great discretion in choosing how it will regulate, it has no discretion as to whether it will regulate, AT\&T v. FCC, 572 F.2d 17, 26 (2d Cir.), cert. denied, 439 U.S. 875 (1978), and it cannot simply substitute competition for regulation, Hawaiian Tel. Co. v. FCC, 498 F.2d 771, 777 (D.C. Cir. 1974). See also ACLU v. FCC, 523 F.2d 1344, 1350-51 (9th Cir. 1975); Philadelphia Tel. Broadcasting Co. v. FCC, 359 F.2d 282, 284 (D.C. Cir. 1966).

14. United States v. Western Elec. Co., 1956 Trade Cas. 71,134, 71,138 (D.N.J. 1956). See also notes 91-92, 190 and accompanying text infra.

15. The FCC initiated its First Computer Inquiry in 1966, reached a final decision in 1971, and ultimately resolved the matter through litigation ending in 1973. Regulatory and Policy Problems Presented by the Interdependence of Computer and Cominunications Services and Facilities, 28 F.C.C.2d 291 (1970) (tentative decision), 28 F.C.C.2d 267 (1971) (final decision), aff'd in part sub nom. GTE Serv. Corp. v. FCC, 474 F.2d 724 (2d Cir. 1973), decision on remand, 40 F.C.C.2d 293 (1973).

16. Compare the Comperitive Carrier notice, 77 F.C.C.2d at 310 (rate regulation as applied to nondominant carriers appears to be obstructive), with the discussion of the House bill at note 21 infra (on petition, the FCC can deregulate all carriers, including dominant ones, in a coinpetitive market).

17. See FCC Acts to Deregulate Telecommunications, 38 Cong. Q. WeEkLy Rep. 993, 993 (Apr. 12, 1980).

18. Amendments to the Communications Act of 1934: Hearings on S. 611 and S. 622 Before the Subcomm. on Communications of the Senate Comm. on Commerce, Science, and Transportation, 96th Cong., 1st Sess. 408 (1979) [hereinafter cited as Amendments Hearings]. 
favored and that the FCC must pursue policies compatible with competition would greatly aid the Commission in its efforts to deregulate the industry. ${ }^{19}$

Two bills considered in the last session of Congress, one written by Representative Lionel Van Deerlin and one by Senator Ernest Hollings, would lave taken a broad approacl to telecommunications reform by annending the Communications Act of $1934 .^{20}$ Representative Van Deerlin's bill would have established deregulation procedures for services other than monopoly services. ${ }^{21}$ The FCC would retain authority over otherwise unregulated carriers for tluree purposes: to ensure that they pay for interconnection into local exchange networks, ${ }^{22}$

19. Although the current regulatory system has adapted to technological changes, that process has been uncertain and the results fragmentary. Consider the statement of Larry Darby of the FCC Common Carrier Bureau:

Each Commission decision affecting the kind or degree of deregulation or competition in intercity communications markets has been preceded by substantial-and some would say wasteful-administrative proceedings within the Commission. Major decisions, of course, have been followed by appeals to the courts, and even more litigation. Thus, uncertainties and differences regarding the meaning of the 1934 act have slowed the pace of the introduction of competition, new services, and, I believe, new technology, as well. Id. at 408.

See S. 2827, 96th Cong., 2d Sess. $\$ 203,126$ Cong. REC. S7018 (daily ed. June 13, 1980) (amending 47 U.S.C. $\$ 20 \mathrm{I}$ ) [heremafter cited without cross-reference as S. 2827]: "It is the policy of the United States to rely wherever and whenever possible on full and fair marketplaee competition to provide all telecominunications services, and thereby to reduce and eliminate unnecessary regulation." S. 2827 § 204, 126 CONG. REC. S7019 (daily ed. June 13, 1980) (amending 47 U.S.C. § 202) provides:

The Commission shall exercise only so much of the powers conferred upon it under this title as is essential to the purposes of this Act, and shall, whenever necessary, revise, reduce, or eliminate any rule or regulation prescribed pursuant to this title witl respect to any telecommunications service or carrier operating in a geographic area or market as competition develops.

See H.R. 6121, 96th Cong., 2d Sess. § 2(a) (1980) (amending 47 U.S.C. § 201) [hereinafter eited without cross-reference as H.R. 6121]:

In achieving the purposes specified in this section, competition and the private sector shall be relied upon to the maximum extent possible to determine the availability, variety, quahity, and cost of domestic telecommunications services, faeilities, and products. The Commission shall exercise regulatory authority, im accordance with the provisions of this title, only to the extent necessary-

. .

(3) to foster a competitive environment;

(5) to carry out the transition to a fully competitive communications industry in accordance with the provisions of this Act.

20. 47 U.S.C. $8 \S 151-609$ (1976).

21. H.R. 6121 \& 2(b)(2)(A) (amending 47 U.S.C. § 214). AT\&T or any other earrier could petition the FCC for deregulation of a service offering. The FCC would grant this petition unless the carrier failed to show that the pertinent market was effectively competitive and the Commission found that granting the petition would not serve the public convenience and necessity. $\int d$.

Carriers other than AT\&T could apply for "fast traek" deregulation within 90 days (or, if the Commission considered a time extension to be necessary, 180 days), with the Commission directed to approve the deregulation unless it finds that doing so would not serve the public convenience and necessity. $I d$.

22. H.R. 6121 \& 2(a) (amending 47 U.S.C. \& 201). 
to see that carriers take appropriate action to promote the nation's defense and emergency preparedness, ${ }^{23}$ and to ensure that ordimary long distance service contmues to be universally available on reasonable request at affordable rates. ${ }^{24}$ AT\&T could enter unregulated markets only through a separate subsidiary. ${ }^{25}$

Senator Hollings' bill was similar, although less explicit as to low deregulation would proceed. Within the general guidelines set out in the bill, the FCC was to determine which services it should continue to regulate $^{26}$ and what requirements it should impose on various regulated carriers. ${ }^{27}$ The bill would impose the separate subsidiary requirement not only on AT\&T, but also on the next five largest carriers. ${ }^{28}$

Although neither bill reached the floor of Congress, ${ }^{29}$ each represented the culmination of several years' efforts to bring the 1934 Act and the regulatory policies spawned by it up to date witl the realities of modern telecommunications. Since eacli is likely to be tlie starting poimt for future attempts to amend the Act, this Comment will examme the bills as they dealt with certam central issues.

Part I of this Comment describes the current structure of the telecommunications industry and the firms that comprise it. Part II discusses telecommunications regulation, the pressures put on the regulatory system by recent technological changes, and the FCC response to those pressures. Part III exammes several of the key issues raised by reforin legislation and suggests the optimal resolution of those issues.

\section{INDUSTRY STRUCTURE}

The focus of this Comment is the domestic telecommunications common carrier industry. ${ }^{30}$ This imdustry is one of the country's largest

23. Id.

24. Id.

25. Id.

26. S. $2827 \S 226,126$ CoNG. REC. S7026 (daily ed. June 13, 1980) (adding 47 U.S.C. $\S 236$ ).

27. Id. $\S 207,126$ CoNG. REC. $\$ 7019$ (daily ed. June 13, 1980) (amending 47 U.S.C. $\S 205$ ).

28. Id. $\S 205,126$ CoNG. REC. $\$ 7019$ (daily ed. June 13, 1980) (amending 47 U.S.C. $\$ 203$ ).

29. House Panel Action Buries Telecommunications Bill for the Current Session, 38 CoNG. Q. WEEKLY REP. 2909 (Oct. 4, 1980).

30. "'Telecommunications' is the transmission of information over long distances by means of cables or radio waves; the information may take the form of voice, pictures, or data." Note, Recent Federal Actions Affecting Long Distance Telecommunications: A Survey of Issues Concerning the Microwave Specialized Common Carrier Industry, 43 GEo. WASH. L. REv, 878, 879-80 (1975) (footnotes omitted). A common carrier is one that holds itself out to the public as providing telecommunications to all members of the public on a nondiscriminatory basis. See National Ass'n of Regulatory Util. Comm'rs v. FCC, 533 F.2d 601, $608-09$ (D.C. Cir. 1976). While this Comment addresses the central issues raised by the recent telecommumications reform bills, it is somewhat narrower than the bills. This Comment does not address the effeets that the bills would 
and most dynamic, with annual revenues of approximately sixty-five billion dollars and a growth rate of twelve percent. ${ }^{31}$ The telephone sector dominates the imdustry, comprising some ninety-seven percent of total revenues and investment, while the telegraph sector accounts for most of the remainder. ${ }^{32}$ The dominant entity within the industry is the Bell Systein, which is coinprised of AT\&T, ${ }^{33}$ with its Long Lines Department, Western Electric, Bell Laboratories, ${ }^{34}$ and twenty-three associated telephone coinpanies, known as "operating companies," that provide local service in their franchise areas. ${ }^{35}$ In 1978 Bell had assets of 103.3 billion dollars, operating revenues of 41 billion dollars, and net plant worth of 90.4 billion dollars. ${ }^{36}$

Bell provides regular telephone service in conjunction with its "partners," the 1,488 independent telephone companies that provide local and long distance service to those portions of the nation not served by Bell's operating coinpanies. The independents serve over half the geographic area of the Umited States, ${ }^{37}$ but since they serve primarily rural areas, they account for less than twenty percent of total domestic telephone service as measured by the number of telephones. ${ }^{38}$ The in-

have on the equipment industry, see H.R. 6121 §§ 2(a) (amending 47 U.S.C. $\S 201$ ), 3(d) (adding 47 U.S.C. § 233); S. 2827 \& 226, 126 CoNG. REC. S7025 (daily ed. June 13, 1980) (adding 47 U.S.C. § 234); imternational telecommunications, see S. 2827 \& 227, 126 CONG REC. S7026 (daily ed. June 13,1980 ) (adding 47 U.S.C. $\$ \S 240,241$ ); or broadcasting, see S. $2827 \S \S 301-308,126$ CONG. REC. S7029-30 (daily ed. June 13, 1980) (amending 47 U.S.C. $\$ \S 301,307,309,315,318,319,396$, and adding 47 U.S.C. $\$ \S 332-334)$.

31. Geller, Past and Future Telecommunication Policy Directions, 47 TELECOM. J. 313 (1980); see Customer Interconnection, 75 F.C.C.2d 506, 518 (1980) (Second Report).

32. Geller, supra note 31, at 313; Domestic Telecommunications Common Carrier Policies: Hearings Before the Subcomm. on Communications of the Senate Comm. on Commerce, Science, and Transportation, 95th Cong., 1st Sess. 64 (1977) (statement of Richard Wiley, Chairman of the FCC) [hereinafter cited as Wiley].

33. Because AT\&T oversees the operations of the Bell System, "AT\&T" and "Bell" will be used interchangeably in this Comment. For a more complete description of Bell's organization, see Ferrell, Bell System Structure, 47 Telecom. J. 338 (1980).

34. Bell Laboratories is owned jointly by AT\&T and Western Electric, each holding a $50 \%$ share. $I d$. at 340 .

35. The operating companies receive services from other departments of Bell-research and development, equipment supply, long distance connections, and central staff services-under license contracts. These contracts are descendants of the contracts between Bell and the local telephone companies that Bell hicensed to use its telephone patents in the late 1800 's. Bell first acquired stock in local companies before 1893, when its patents began to expire. Bell now holds a majority interest in twenty-one of the operating companies. Id. at 339-41. The Second Computer Inquiry decision proinpted Bell to increase its ownership interest im some of these companies. Telecommunications Bill Appears Trapped by Logjam But Maneuvering Continues, 38 Cong. Q. Weekly Rep. 2613 (Aug. 30, 1980).

36. Competitive Carrier Rulemaking, 77 F.C.C.2d at 318.

37. Amendments Hearings, supra note 18, at 1017 (statement of Weldon Case, United States Independent Telephone Ass'n).

38. Economic Implications and Iuterrelationships Arising From Policies and Practices Relating to Customer Interconnection, Jurisdictional Separations and Rate Structures, 75 F.C.C.2d 506, 518 (1980). See also United States Independent Telephone Ass'n, Independent Telephone 
dependents vary tremendously im size, ranging from small family operations to GTE, which serves approximately 14.3 million telephones and whose operating revenues account for 7.8 percent of the domestic telephone market. ${ }^{39}$ Bell and the independents characterize themselves as partners because they cooperate in conducting long-range planning and in resolving day-to-day technical problesns. More importantly, their networks are interconnected and Bell compensates the independents for the additional costs caused by interconnection with the Bell systein. ${ }^{40}$

Bell and the independents together form the dominant telephone network in the United States. The services provided by this network can be divided imto local (intraexchange) and long distance (interexchange) services. Local service is provided by wire; long distance transmission inay be conducted entirely along wires, but is often switched from local wires to microwave relay facilities or in some cases to satellites for intercity transmission. Local service is generally considered a "natural monopoly" in which coinpetition would be econonically inefficient, ${ }^{41}$ and no significant competition has yet arisen in local markets. ${ }^{42}$ On the other hand, long distance markets have been inarked by mcreasing competition in recent years. ${ }^{43}$ These new competitors offer ordinary voice transmission services, ${ }^{44}$ video transmission services, and a variety of specialized services. ${ }^{45}$

A nuinber of coinpanies currently coinpete with Bell and the independents in the provision of long distance voice transmission or specialized services. For example, Western Umon Telegraph Co. holds a inonopoly in the domestic telegraph service market. ${ }^{46}$ Since 1971,

Industry in the United States, 47 Telecom. J. 342, 352 (1980) [hereinafter cited as Independent Telephone]. 1017.

39. Second Computer Inquiry, 77 F.C.C.2d at 471; Amendments Hearings, supra note 18, at

40. An example of such a cost would be the expense of hiring more operators to handle the additional traffic generated. For a detailed discussion of these payments, see notes 85-89, 150-77 and accoinpanying text infra.

41. See text accoinpanying notes 69-73 infra.

42. But see uote 53 infra (discussion of the new service proposed by the Xerox Corporation).

43. See text accoinpanying notes 100-34 infra.

44. See text accoinpanying note 8 supra.

45. These specialized services include a broad range of data transinission services. Generally, nonvoice inforination is transınitted over telephone lines by way of "private lines." A private hine is an exclusive open telephone line between two designated poimts, reserved for a given user. AT\&T, 74 F.C.C.2d 226, 231 (1979). Under some circumstances a user of telephone services will find it economically feasible to construct its own private lines, but users usually lease the private lines that they need froin a common carrier.

46. Until recently, this was a de jure monopoly for Western Union. However, the FCC has adopted a policy of open entry into this inarket. See Graphnet Sys., Inc., 67 F.C.C.2d 1059 (1978) (Notice of Inquiry and Proposed Rulemaking), 71 F.C.C.2d 471 (1979) (Memorandum Opimion and Order); Regulatory Policies Concerning the Provision of Domestic Public Message Services 
when it acquired AT\&T's TWX teletype service, it has also been the sole provider of domestic teletype services. ${ }^{47}$ Western Union also competes with AT\&T and other carriers in the provision of private lime and video relay services.

Video relay carriers have long provided one-way terrestrial transmission of television signals to cable television systems. ${ }^{48}$ They generally receive television signals at a point twenty to fifty miles from a major city, and send the signals via privately-owned inicrowave relay facilities (with towers at twenty- to thirty-mile intervals) to smaller outlying communities. Video relay carriers are relatively small, operating on a regional basis. As of 1978, fifty-five such carriers were im operation; the number has generally declined over the years due to mergers and acquisitions. ${ }^{49}$

Specialized common carriers are a diverse group of telecommunications carriers. They originally earned their label by successfully arguing before the FCC that they were prepared to meet the specialized needs of business and data communications users that were not being met by AT\&T. The label is somewhat misleading, smce soine of these carriers-1nost notably MCI Telecommunications Corp. and Southern Pacific Communications Co.- - have attracted inore attention by competing in the traditional long distance market than by providing specialized services. However, it was on the basis of the claim that such new businesses would compete with AT\&T by offering a wide variety of specialized services that the FCC in 1971 adopted a pohicy of open entry for specialized common carriers ineeting its financial and teclinical requirements. ${ }^{50}$ After a "shakedown" period followed by a number of consolidations, the specialized common carrier field features several financially solid firms. ${ }^{51} \mathrm{MCI}$ currently operates on a national scale, as does Southern Pacific Communications Co. Several others, including United States Transmission Systems, Inc. (ITT-USTS), an ITT subsidiary; CPI Microwave, which has been acquired by Western Union; and Western Telecommunications, Inc., operate regionally. ${ }^{52}$ The special-

by Entities Other Than the Western Union Telegraph Company and Proposed Amendment to Parts 63 and 64 of the Commission's Rules, 75 F.C.C.2d 345 (1980) (Memorandum, Opinion, and Order).

47. Competitive Carrier Rulemaking, 77 F.C.C. $2 \mathrm{~d}$ at 311 n.5.

48. These carriers also serve television broadcast stations in some instances, and to a limited extent compete in providing such point-to-point services as data, facsimile, and voice transmission. See id. at 321 .

49. Id.

50. Specialized Common Carrier Serv., 29 F.C.C.2d 870 (1971) (First Report and Order), affd sub nom. Washington Util. \& Transp. Comm'n v. FCC, 513 F.2d 1142 (9th Cir.), cert. denied, 423 U.S. 836 (1975).

51. See Competitive Carrier Rulemaking, 77 F.C.C.2d at 325.

52. Id. at 319 . 
ized common carriers typically offer point-to-point voice, facsimile, and data communications over their own long distance microwave networks, with local loops usually provided by the operating conipany, either Bell or an independent. ${ }^{53}$ Most also offer switched servicesinterconnection with a number of different locations and terminals from a given point-and those that serve a broad range of cities can offer equivalents to traditional long distance service (Message Toll Service, or MTS) and Wide Area Telephone Service (WATS). ${ }^{54}$

Domestic satellite carriers transmit signals between earth stations and satellites in geostationary orbit rather than along strings of relay towers. In 1972, the FCC adopted a policy of open entry into the domestic satellite field similar to its pohicy with respect to specialized common carriers, ${ }^{55}$ but as yet little actual entry has occurred. While satellite systems may be relatively econonnical to operate, initial entry costs are very high, ${ }^{56}$ and this has inhibited new entry. To date only three companies provide donestic satellite services entirely over their own facilities-RCA Commumications, Inc.; Western Union; and AT\&T/GSAT, the joint venture of AT\&T and GTE. ${ }^{57}$ All three provide private line services-voice, data, and video-while AT\&T/GSAT also provides MTS and WATS service. Other companies lease satellite capacity froin RCA Communications or Western Union and use it in conjunction with their own earth stations. ${ }^{58}$ For example, American Satellite Corp. leases capacity froin Western Union to provide voice, data, and occasional video services, and several other satellite carriers compete with video relay carriers through the use of

53. This is usually Bell, since it doininates the urban inarkets that the specialized common carriers serve. In some cases the subscriber or the carrier provides the local links. The Xerox Corporation proposes to bypass the local telephone network with its telecommunication network (XTEN). XTEN would use microwave radio links between subscribers and local "nodes," and between nodes and a main city. The network would offer electronic document retrieval, forwarding, and encryption, as well as data communication and teleconferencing over high-speed digital communications lines ainong 200 metropolitan areas. See New Data Networks, 47 Telecom. J. 374,375 (1980).

54. WATS is a long distance telephone service for nonresidential use. Available on both an outward-bound and inward-bound (" 800 "-number service) basis, it offers customers a flat rate for unlimited calls within a specified area. The FCC has determined that MCI's Execunet service, Southern Pacific's SPRINT IV and V, and ITT-USTS' City-Call services are functional equivalents of MTS and WATS. See MTS and WATS Market Structure, 67 F.C.C.2d 757 (1978) (Notice of Inquiry and Proposed Ruleinaking), 73 F.C.C.2d 222 (1979) (Supplemental Notice of Inquiry and Proposed Rulemaking), 77 F.C.C.2d 224 (1980) (Second Supplemental Notice of Inquiry and Proposed Rulemaking).

55. See Domestic Communications-Satellite Facilities, 34 F.C.C.2d 1 (Memorandum Opimion and Order), 35 F.C.C.2d 844 (Second Report and Order), 38 F.C.C.2d 665 (1972) (Memorandum Opinion and Order).

56. Competitive Carrier Rulemaking, 77 F.C.C.2d at 320.

57. Id. at 319 .

58. Because they operate in part by using facilities leased from other carriers, these companies may also be classified as "resale carriers." See text accompanying notes 60-64 infra. 
RCA Communications' satellite facilities. ${ }^{59}$

A final category of competitive telecommunications carriers is that of resale carriers. These companies lease transmission capacity from other carriers, usually AT\&T, and use their own switching equipment ${ }^{60}$ and computers to modify this underlying service, thereby providing a special purpose network capable of transmitting data and facsimile with special features attractive to busmess users. ${ }^{61}$ For example, the facitities of Telenet Systems, Inc. and Graphnet Systems, Inc. permit communication between computer terminals that differ as to transmission speeds, display formats, and other features. ${ }^{62}$ In addition to the satellite resale carriers and Telenet and Graphnet, five other resale carrier systems have been authorized by the FCC, and applications for several more are pending. ${ }^{63}$ The fact that there is more entry into resale carriage than into specialized common carriage and doinestic satellite carriage is due to smaller mvestment expenses and shorter construction delays in that field. ${ }^{64}$

\section{II}

\section{REGULATION OF THE INDUSTRY AND THE RISE OF COMPETITION}

Congress formulated the current system of telecominunications regulation in 1934, and has not changed it significantly since. During the early years of regulation, statutory provisions and institutional constraints combined to shape the regulatory characteristics of the industry. After World War II a number of technological advances altered the face of the telecommunications imdustry and called imto question

59. 77 F.C.C.2d at 320; see Gaines, Specializcd Common Carrier-Competition and Allernalive, in Computer Communications 449 (P. Green and R. Lucky eds. 1975). Satellitc Business Sys., Inc., a venture formed by subsidiaries of IBM Corp., Comsat General Corp., and Aetna Life and Casualty Co., is leasing satellite capacity froin RCA for use by IBM, its only customer at this point. See notes 226-28 and accoinpanying text infro; United States v. FCC, 1980-1 Trade Cas. 78,309 (D.C. Cir. 1980).

60. A switching machine connects various lines so that connected subscribers can communicate with any party in the comnunications network. See Note, Competition in the Telephone Equipment Industry: Beyond Telerent, 86 YALE L.J. 538, 538 n.1 (1977).

61. Competitive Carrier Rulemaking, 77 F.C.C.2d at 320-21. Because of the nature of their service, these resale carriers are often referred to as "value-added" carriers. $I d$.

62. Id. at 322. This service is one of the few offered by Bell's coinpetitors that is not also offered by Bell. However, Bell plans to introduce a state-of-the-art service called Advance Coinmunications Service (ACS). For a description of ASC, see New Dato Networks, 47 TELECOM. J. 374 (1980).

63. Counpetitive Carrier Rulemaking, 77 F.C.C.2d at 320 n.18. The five authorized systems are those of ITT Corporate Communications Systens (now merged into ITT-USTS), ITT Domestic Transmission Systeins (another ITT subsidiary), Tymnet, RCA Global Systeins, Inc., and DHL Cominunications Inc. Telenet has recently been acquired by GTE. See GTE-Telenet Merger, 72 F.C.C.2d 1I1, modified, 72 F.C.C.2d 516 (1979).

64. Competitive Carrier Ruleınaking, 77 F.C.C.2d at 321. 
many of the long-standing regulatory practices. Since 1959, the FCC gradually has begun to adapt to these industry changes, but the evolution of regulation has been halting and inconsistent, and has lagged far behind the pace of industry developinent. The inadequate response of the regulatory system provides impetus for evaluating the reform alternatives considered in Part III.

\section{A. Regulatory Scheme}

The Communications Act of $1934^{65}$ gives the FCC primary responsibility for regulating the telecommunications common carrier industry. While the Act gives the Commission broad discretion in the regulation of telecommunications, it requires that the FCC pursue one prinary goal: universal service. The first section of the Act creates the FCC "[f]or the purpose of regulating imterstate and foreign commerce in communication by wire and radio so as to inake available, so far as possible, to all the people of the United States a rapid, efficient, nationwide, and world-wide wire and radio communication service with adequate facilities at reasonable charges." ${ }^{66}$ This clause, often referred to as the "universal service mandate," is one of the few provisions of the 1934 Act not drawn from prior legislation. ${ }^{67}$ The essence of the mandate is a desire to keep telephone rates, especially for local service, low so that telephone service will be affordable for virtually everyone. Implicit in the mandate is the recognition that the value of telephone service is largely a function of the number of people that can be reached over it. ${ }^{68}$

The universal service mandate has strongly influenced the FCC's regulatory decisions. The Commission used it froin 1934 to the end of the 1960's as a justification for discouraging competition in the industry. The Commission is required by the 1934 Act to limit entry to only those firms that can slow a public need for the proposed service and an

65. Pub. L. No. 73-416, 48 Stat. 1046 (1934), codified at 47 U.S.C. $\$ \$ 151-609$ (1976).

66. 47 U.S.C. $\& 151$ (1976).

67. Loeb, The Communications Act Policy Toward Competition: A Failure to Communicate, 30 FED. COMM. L.J. 1, 18 (1977).

68. The goal of universal service has been substantially achieved, since $97 \%$ of Ainerican hoines receive service (as compared with $33 \%$ when the Act was passed). See Independent Telephone, supra note 38 , at 351.

A recent speaker offered this rendition of the universal service mandate:

The Congress must guarantee that the average American, the proverbial "little old lady in tennis shoes," continues to have necessary access to telephone service at reasonable rates. This principal [sic] has been the foundation of our current telephone systern and 1 subinit, it inust remain the foundation. We inust not sacrifice on the altar of reforn the interests of the "little guy."

Amendments Hearings, supra note 18, at 1323 (statement of Edward Larkin, National Ass'n of Regulatory Utility Comm'rs). 
ability to meet that need. ${ }^{69}$ Until recently, the FCC had never' found such a public need. The Commission long beheved that competition in the provision of telephone services was not in the public interest because the industry was a "natural monopoly." A natural inonopoly exists if there are long-run economies of scale in the production of a good or service such that the industry's total output can be produced inost efficiently by a single large firm. If inultiple firms exist, inarket forces eventually will drive out all but one. ${ }^{70}$ Competition in a natural inonopoly environment produces wasteful and imconvenient duplication of facilities ${ }^{71}$ inhibiting umiversality of service by increasing costs unnecessarily. ${ }^{72}$ Technology is a key factor here, because long-run economies of scale generally exist where there are high fixed capital costs such as teleplione cable, meaning that average umit production costs drop substantially as output-and thus, a firm's size-increases. ${ }^{73}$ Technological changes can eviscerate economies of scale and reduce barriers to entry in an imdustry.

The FCC historically has felt hittle need to oversee carriers' planning and marketimg decisions. Instead, it has operated in a passive mode, simply reviewing the service and rate proposals of carriers to ensure that they provide adequate, nondiscriminatory service at reasonable rates. ${ }^{74}$ The nonimtrusiveness of the regulatory scheme is at least in part due to the FCC's lack of resources with which to regulate the common carrier industry. Only about fifteen percent of the FCC's total budget is allocated to the Common Carrier Bureau. ${ }^{75}$

69. 47 U.S.C. $\$ 214$ (1975).

70. General accounting Office, Developing a Domestic Common Carrier TeleCOMmunications Policy: What ARe the Issues? 6-7 (Jan. 24, 1979) (Comptroller General's Report to the Congress); Posner, Natural Monopoly and Its Regulation, 21 STAN. L. REv. 548 (1969).

71. S. Breyer, Natural Monopoly: The Problem of Competition in Longlines Telecommunications 13-14 (undated) (on file with the California Law Review).

72. Competition in the Telecommunications Industry: Hearings Before the Subcomm. on Communications of the House Comm. on Interstate and Foreign Commerce, 94th Cong., 2d Sess. 68 (1976) (statement of Paul Henson, Chairman of United Telecommunications, Inc.) [hereinafter cited as Henson].

73. Note, supra note 30 , at 894 . Some would go beyond this and say that it is the physical nature of the capital investment that is determinative:

If you look at what we today consider to be natural monopolies, they are characterized by some hard-wired, physical connection to the customer's premises-a line from a pole for electricity, or for telephone service, attached to a house; or a gas or water pipeline running under the ground to a person's house.

Amendments Hearings, supra note 18, at 310 (statement of Charles Zielinski, New York State Public Service Comm'n).

74. Pursuant to 47 U.S.C. $\$ \S 201,202$ (1976). See Mathison \& Walker, Regulatory and Economic Issues in Computer Communications, in COMPUTER CoMmUNiCATIONS 5, 6 (P. Green \& R. Lucky eds. 1975).

75. Office of Management and Budget, Budget of the United States GovernMENT, FISCAL YEAR 1980 (1980). 
Viewed in terms of regulatory budget dollars per revenue dollar of the industry being regulated, the FCC spends only one-fifth as much to regulate the communications carriers as the Interstate Commerce Commission (ICC) and the Federal Power Commission [now the Federal Energy Regulatory Commission] do to regulate the transportation and energy industries, respectively. ${ }^{76}$

The FCC shares regulation of the telecommunications common carrier industry with state Public Utility Commissions (PUC's). ${ }^{77} \mathrm{At}$ the state level, where the regulatory agencies are also responsible for such other intrastate public utility services as gas, electricity, water, and transportation, regulation of telecommunications is haphazard at best. To the extent that state PUC's do adopt pohicies on telecommunications issues, they often conflict with federal policies. In the early 1970 's, for example, state PUC's, believing that revenues from the rental and sale of telephone equipinent by Bell companies subsidized local services and lielped to keep rates low, unsuccessfully attempted to block implementation of the FCC's policy ${ }^{78}$ of opening the equipment market to competition. ${ }^{79}$

\section{B. Characteristics of the Industry Under Traditional Regulation}

The early history of the American telecommunications industry was marked by periodic swings from monopoly to competition and back. ${ }^{80}$ In the twenty-five years following the passage of the Communications Act, the FCC adopted a protective stance toward Bell's monopoly, ${ }^{81}$ and paid hittle attention to the structure of the industry as a whole. ${ }^{82}$ As a result, Bell was able to consolidate its monopoly position. Both local telephone service ${ }^{83}$ and toll telephone service became

76. Mathison \& Walker, supra note 74 , at 6 .

77. Id. State PUC's have jurisdiction over local and intrastate long distance services. This jurisdictional scheme should be reexamined in light of imdustry developments. See notes 139-49 and accompanying text infra.

78. See Carterfone, 13 F.C.C.2d 420 (1968).

79. The PUC's adopted the position that, contrary to Carterfone, customers could not connect non-Bell equipment into the telephone network. This position was rejected in North Carolina Util. Comm'n v. FCC (Telerent), 537 F.2d 787 (4th Cir.), cert. denied, 429 U.S. 1027 (1976). See Note, supra note 60 .

80. For a detailed discussion of the history of the telecommunications industry, see Trebing, Common Carrier Regulation-The Silent Crisis, 34 LAW \& ConTEMP. ProB. 299, 303-10 (1969).

81. Note, supra note 30 , at 883 .

82. Trebing, supra note 80 , at 306. During the 1930's the FCC conducted a study of the industry structure, see FCC, REPORT ON THE INVESTIGATION OF THE TELEPHONE INDUSTRY IN THE UNITED STates, H.R. Doc. No. 340, 76th Cong., 1st Sess. (1939), but this was at the behest of Congress, and it led to no further action. See Wiley, supra note 32, at 55-56.

83. Wiley, supra note 32 , at 55 n.2. The number of independents has declined steadily smce the early 1920 's, from over 9,000 to 1,488 today. Wiley, supra note 32, at 94 (Attachment B); Independent Telephone, supra note 38, at 351. 
joint Bell/independent monopolies, leaving only the private line market showing signs of competition. ${ }^{84}$

An ongoing issue is the problem of allocating telephone companies' costs between intraexchange and interexchange service; many facilities are used for both. When this "separations" problein first arose in the early 1910's, regulators adopted the "board-to-board" primciple of separations. They set local rates to cover the costs of all local equipinent (telephones, local loops, and local exchanges), and permitted interexchange rates to cover only the additional costs of providing long distance service: the cost of long lines and the compensation paid by Bell to the local companies for their extra operating costs due to their role in providing long distance service. ${ }^{85}$ When the FCC adopted this principle, toll charges based on mcremental costs alone were high, so that requiring toll charges also to cover a portion of the costs of facilities used jointly with local exchanges might have seriously retarded toll calling. ${ }^{86}$ By the early 1940 's, however, technological advances and increased voluine in the toll sector had made calling substantially cheaper, while at the sanie time there was pressure from the telephone companies to nicrease local rates. ${ }^{87}$ In 1943, the FCC adopted the "station-to-station" principle of separations, in which a portion of the joint costs is borne by toll users, easing this imbalance. ${ }^{88}$ Since then, further technological change and growth in demand have continued the downward pressure on toll rates. The FCC, in cooperation with the state PUC's and the industry, typically has responded by reducing toll rates by less than the full amount possible, and changing the separations rules to allocate inore of the joint costs to interexchange services, so as to absorb the rest of the potential reduction in rates. Over the years, then, interstate revenues have been used increasingly to keep local rates low, ${ }^{89}$ thereby promoting the FCC's goal of universal service.

84. Wiley, supra note 32, at 95 (Attachment B).

85. S. Breyer, supra note 71 , at 22.

86. Henson, supra note 72 , at 75 .

87. Id. at 80 .

88. Id. at 77. An early impetus for the change was the Supreme Court's decision in Smith v. lllinois Bell Tel. Co., 282 U.S. 133 (1930). In that case, the state commission, using the board-toboard principle, had not allocated any of the local exchange fixed costs to interexchange service. The Court said:

While the difficulty in making an exact apportionment is apparent, and extreme nicety is not required, . . . it is quite another matter to ignore altogether the actual uscs to which the property is put. It is obvious that, unless an apportionment is made, the intrastate service to which the exchange is allocated will bear an undue burden . . . .

Id. at 150-51. However, when the case returned after remand, the Court approved a procedure whereby the District Court had offset an assignment of local exchange costs to interstate service by an assignment of local revenues to such service. Lindheimer v. lllinois Tel. Co., 292 U.S. 151 (1933).

89. Henson, supra note 72 , at 80 . Separations revenues are allocated under a formula worked out among Bell and the local operating companies, both Bell and independent. A certain 
Another long-standing characteristic of telecommunications regulation is nationwide rate averaging. Rate averaging is the policy of charging equally for interstate calls of the same distance made at the same time, regardless of differing costs along different routes. This practice agam reflects the desire to ensure universal service. Such averaging allows customers im rural areas, where the unit costs of providing toll service are relatively high because of the low volume, to pay the same for comparable interstate toll service as those in urban areas. ${ }^{90}$

In 1949, the Justice Department brought an antitrust suit to compel the divestiture of Western Electric, but the resultimg consent decree, issued in 1956, ${ }^{91}$ stopped far short of that remedy. Instead, it simply restricted AT\&T and Western Electric to the provision of common carrier communications services and the manufacture of equipment for such purposes. ${ }^{92}$

Even after the 1956 consent decree, then, the common carrier industry was primarily a regulated monopoly dominated by the Bell system. The FCC's traditional inethods of regulation were successful while the agency operated in such an industry structure, but the developinents of the next two decades brought a need both to foster increased competition in the industry and to more closely inonitor Bell to prevent it froin pricing in a predatory manner and subsidizing its competitive operations with its monopoly revenues.

\section{Technological Advances}

A series of technological developments beginning during World War II called mto question the regulatory practices and philosophies described above-apphication of the natural monopoly theory to the industry, the use of separations procedures to subsidize local service, and nationwide rate averaging. The inost important innovations have been microwave radio transmission, satellite communications, digital

percentage of total interexchange revenues is set aside each month by each company, with the remainder of the revenues going to Bell. Monies are then transferred among the companies so that each company receives the amount owed to it under the formula. Transfers among Bell entities are called "divisions of revenue," while transfers between Bell and independent companies are called "settlements," yet both types of companies receive the same treatment under the formula. MTS and WATS Market Structure, 77 F.C.C.2d 224, 227 (1980).

90. Henson, supra note 72, at 82-83. The FCC stated the principle underlying rate averaging in Department of Pub. Serv. v. Pacific Tel. \& Tel. Co., 8 F.C.C. 342, 364 (1941): "[I]n the absence of other controlling considerations the basic rule to be observed in the determination of reasonable charges is that there shall be collected from each user 'equal charges for equal services.'"

91. United States v. Western Electric Co., 1956 Trade Cas. 71,134 (D.N.J. 1956) (consent decree).

92. Id. at 71,137-38. The Justice Department had also sought to have Bell institute coinpetitive bidding in its equipment purchases and nondiscrinuinatory patent licensing with reasonable royalties. The consent decree provided only for the former. Id. at 71,139 . 
electronics, and solid state circuitry. ${ }^{93}$ These technological advances have affected the telecommunications industry by making competition in established areas of service feasible and by creating a need for suppliers of new services.

First, new developments in microwave and satellite communications lowered capital investment requirements, making new entry much easier for prospective competitors and raising the question whether the natural monopoly theory continued to apply to long distance communications. Microwave radio transmission developed as an offshoot of the wartime research in radar. In practice it involves transmitting narrow beams of extremely high frequency radio energy between towers erected at intervals of twenty to thirty miles. The high frequencies used permit large numbers of individual messages to be carried by a single beam, causing the per-unit cost of long distance microwave communications to be lower than the comparable cost of wire communication..$^{94}$ The nicrowave signal is also less subject to degradation over long distance.

Coinmunications satellites came into service in the early 1960's. They coinbined microwave transmission and digital and solid state electronics with the rocket technology developed in the space and defense programs. Microwave radio requires tine-of-sight transmission; satellites, on the other hand, serve as a single relay station, elimmating the need for numerous relay stations. ${ }^{95}$ Thus, although the investment required to start a satellite systen might be quite high, a "nationwide network" can be relatively inexpensive.

While these developinents made it easier for competition to develop in traditional telecominunications markets, computer advances greatly expanded the variety of specialized communications services needed by customers. Digital eleetronics had a significant effect on the diversity of telecommunications needs and the provision of telecommunications services. Digital signals--high-speed on/off electrical signals used to transmit, store, and process information ${ }^{96}$-are the foundation of the coinputer and data processing industry. The need for the transmission of digital signals stems froin three developments: time-sharimg of coinputers by large numbers of users in different locations, remote

93. Wiley, supra note 32, at 56. All of these developments had their origins in government research and development, but their applications spilled over imto private common carrier communications. Despite its vertical integration, Bell was no longer the mam innovator in the industry. Trebing, supra note 80 , at 307-08.

94. Wiley, supra note 32, at 56; Johnson, Boundaries to Monopoly and Regulation in Modern Telecommunications, in COMMUNICATIONS FOR TOMORROW 127, 130 (G. Robinson ed. 1978).

95. Johnson, supra note 94, at 130-31.

96. Wiley, supra note 32 , at 57 . 
batch processing, 97 and the need for computers to "talk" to one another. ${ }^{98}$ The analog voice network was unable to serve these digital communications needs adequately. It required the use of costly imterface devices and distortion-correcting ineasures, the latter of which were not wholly effective in reducing the error rate. It also required too much time to set up calls-ten to fifteen seconds for computer messages lasting only a few seconds. Finally, it did not permit simultaneous transmission of messages in both directions. ${ }^{99}$ Solid state electronics developments during this period-the transistor, integrated circuits, and the ninicomputer-advanced both computer technology and telecommunications technology.

\section{The Introduction of Competition}

The result of the combination of events described above was that a large nunber of prospective competitors filed applications to provide new services. The changes in the telecommunications imdustry ultiinately forced the FCC to shift from protecting nionopoly to allowing competition, but that shift was slow im coming.

The first step in the movement was the Above 890 decision, ${ }^{100}$ in which the FCC decided to allocate frequencies to businesses desiring to build and operate microwave networks for their own use. The Commission felt that permitting private use of inicrowave would allow businesses to meet specialized needs that were not being filled by conunon carriers. In addition, the Commission felt that the decision would foster an expansion of communications needs that in turn would promote innovation by equipinent nianufacturers and the industry generally. ${ }^{101}$ Although proconipetitive, the Above 890 decision had only a slight direct inipact. ${ }^{102}$

The next major developnient, the FCC's $M C I$ decision, canie ten

97. Batch processing is the use of punched cards (inputs and outputs) to reduce the amount of computer idle time. Remote batch processing is the use of input/output terminals so that a computer can be used effectively by someone not in proximity with the inachine. Wiley, supra note 32, at 96 (Attachment B).

98. Id. at $96-97$.

99. Id. at 98-99; Johnson, supra note 94 , at 130.

100. Allocation of Frequencies Above 890 Mc., 27 F.C.C. 359 (1959), modified, 29 F.C.C. 825 (1960).

101. 27 F.C.C. at $413-14$.

102. As of March 1964, "only one major private microwave system of a type involved in the Above 890 case [was] in operation." TELPAK Service and Channels, 38 F.C.C. 370, 382 (1964). The Commission felt this was due to AT\&T's TELPAK rates, introduced shortly after the resolution of $A$ bove 890 . Id. These new rates offered significant discounts for bulk users of private hine services-the saine group that would be tempted to build private networks. See TELPAK Service and Channels, 37 F.C.C. 1111, modified, 38 F.C.C. 370 (1964), aff d sub nom. American Trucking Ass'ns, Inc. v. FCC, 377 F.2d 121 (D.C. Cir. 1966), cert. denied, 386 U.S. 943 (1967). 
years later. ${ }^{103}$ The $M C I$ case marked the emergence of a new era in the regulation of the telecommunications industry. In 1969 the FCC granted MCI's application to service Chicago, St. Louis, and nine intermediate points as a common carrier in the private line market, in direct competition with Bell and Western Union. ${ }^{104}$ MCI's system, "designed to meet the interoffice and interplant communications needs of small businesses,"105 offered greater flexibility than those of the established carriers. It could transmit voice, data, facsimile, teletype, and other signals and accept both digital and analog signal inputs. ${ }^{106}$ In addition, MCI was more liberal than the established carriers concerning the connection of custoiner-provided equipment and the use of leased channels. ${ }^{107}$ It permitted up to five customers to share a channel and offered lower rates for half-time users of channels. ${ }^{108} \mathrm{MCl}$ 's rates were generally lower than Bell's, but this may only have been a reflection of the fact that MCI, unlike the existing carriers, did not provide local intercomrection. ${ }^{109}$ Although permitting MCl's entry entailed a duplication of facilities along the Chicago-St. Louis corridor, the Commission felt that the duplication was justified because $\mathrm{MCI}$ could capture a latent market. ${ }^{110}$

The $M C l$ decision prompted a large number of other prospective entrants to apply for permission to construct microwave networks and enter the specialized private line market. Rather than decide the entry question on a case-by-case basis, the FCC instituted a rulemaking proceeding to resolve a number of common policy and procedural questions." ${ }^{11}$ The fundamental question was "[w]hether as a general policy the public interest would be served by permitting the entry of new carriers in the specialized communications field." I12 In Specialized Common Carriers, decided in 1971, the FCC formally adopted a policy

103. Microwave Communications, Inc., 18 F.C.C.2d 953 (1969), modifications granted, 27 F.C.C.2d 380 (1970). MCI applied for the authorization in 1963. B. OWEN \& R. BRAEUTIGAM, The Regulation Game 220 (1978).

104. 18 F.C.C.2d at 953.

105. Id.

106. Mathison and Walker, supra note 74 , at 16.

107. 18 F.C.C.2d at 959. MCI did not restrict the sphitting of channels for voice, facsimile, and data transmissions. Also, it subdivided its voice channels into narrower increments than did the existing carriers. Id. Although all common carriers are now prohibited from enforcing these restrictions, at the time such liunits were legal. See notes 125-27 and accompanying text infra.

108. 18 F.C.C.2d at 954.

109. In other words, customers were required to provide the links between their offices and the nearest $\mathrm{MCI}$ facihty. Id. at $957-58$.

110. Id. at 958-59.

111. Specialized Common Carrier Serv., 24 F.C.C.2d 318 (1970) (Notice of Inquiry), 29 F.C.C.2d 870 (1971) (First Report and Order), aff'd sub nom. Washington Util. \& Transp. Comm'n v. FCC, 513 F.2d 1142 (9th Cir.), cert. denied, 423 U.S. 836 (1975).

112. Id. at 327 . 
favoring entry into the private line market. ${ }^{113}$ The Commission found that entrants would provide new services to customers with specialized needs that had not been inet by the estabhished services. ${ }^{14}$ The Commission declined to determine whether the rise of competition would risk loss of economies of scale, deciding instead to let the entrants test the natural monopoly theory theinselves. It declared: "[I]f an applicant is found qualified, obtains the necessary financial backing, and makes a business judginent to risk that investment . . ., we are not inclined to place further obstacles in its path."115 If competition did result in the loss of economies of scale, the Commission felt that such losses would be offset by the benefits of increased specialization. ${ }^{116}$ Moreover, it saw no reason to believe that competition would harm existimg carriers, simce they presuinably would capture their share of this "rapidly growing market." 117 As to whether the specialized carriers should be able to tie into local exchange networks, the Commission said that "established carriers with exchange facitities should, upon request, permit interconnection or leased channel arrangements on reasonable terms and conditions to be negotiated with the new carriers." 118

With the 1972 Domsat decision, the FCC adopted a similar policy

113. Specialized Common Carrier Serv., 29 F.C.C.2d 870 (1971) (First Report and Order), affd sub nom. Washington Util. \& Transp. Comm'n v. FCC, 513 F.2d 1142 (9th Cir.), cert. denied, 423 U.S. 836 (1975).

114. 29 F.C.C.2d at 906-08. The Commission rejected, $i d$. at 901 , the claim of the established carricrs that under $\S 214$ of the 1934 Act, as apphed to prospective entrants through $\S 309$, entry could not be permitted absent a showing "that there is a need for the proposed services which existing carriers are not now adequately meeting and could not in the future adequately meet." 29 F.C.C.2d at 900 . On the basis of FCC v. RCA Communications, lnc., 346 U.S. 86 (1953), it held that the proper standard was whether entry "would serve the present or future public interests, convenience and necessity." 29 F.C.C.2d at 901 . See also Washington Util. and Transp. Comm'n v. FCC, 513 F.2d 1142, 1155-59 (9th Cir.), cert. denied, 423 U.S. 836 (1975) (upholding the Cominission's application of the RCA Communications standard).

115. Specialized Common Carrier Serv., 29 F.C.C.2d at 927.

116. Id. at 909-10. The Commission adopted the findings of its staff:

The sheer size of the AT\&T organizational structure, its enormous financing requireinents, its vertical integration, and near monopoly position in the provision of communications services may make it slower to perceive and respoud to imdividual specialized requirements and to initiate market and technical innovations. . . . Competition in the specialized communications field would enlarge the equipment market for manufacturers other than Western Electric, and may stimulate technical innovation and the introduction of uew techniques. Moreover, new carriers with smaller scale operations could devote their individual attention to the particular needs to be served, and lacking a captive market, would be under pressure to innovate to produce those types of services which would attract and retain customers.

117. Id. at 912. The Commission noted that private he services accounted for only about four percent of Bell's total revenues. Id. at 911.

118. Id. at 940 . This position was strengthened in 1974 when the Commission held that Bell inust provide its private line service competitors with the same types of facilities that it provides to its own Long Lines Division private line operations. Bell Sys. Tariff Offerings, 46 F.C.C.2d 413, 426-27, aff'd sub nom. Bell Tel. Co. v. FCC, 503 F.2d 1250 (3d Cir. 1974), cert. denied, 422 U.S. 
with respect to satellite systems to be used for domestic communications purposes. ${ }^{119}$ It reasoned that the increased competition would promote both innovation and price reductions im the supply of specialized serviccs. ${ }^{120}$ In order to permit competitors to establish their satellite operations without having AT\&T preempt the field, the Commission temporarily prohibited AT\&T from usmg satellites to offer private line services to nongovernment users. ${ }^{121}$

In a serics of decisions in 1973-1974, ${ }^{122}$ the FCC permitted the entry of certain "value-added" carriers that proposed to lease channels from existing carriers and "combine them with computers and software to transmit data more efficiently and with less error." 123 The Commission felt that an open entry pohicy here was consistent with its Specialized Common Carriers decision. ${ }^{124}$ This open entry policy, however, operated only im theory until the Commission struck down Bell's prohibition on the resale of its private line services.

In 1976 the Commission, with its Resale and Shared Use decision, ${ }^{125}$ increased the likelihood that competitive private line carriers would make inroads imto Bell's long distance monopolies by striking down Bell's restrictions on the resale and sharing of interstate private line services. This move ensured that the value-added carriers would be able to procure facilities for their needs. In addition, it permitted customers of the specialized carriers to obtam small allotments of usefor instance, three minutes at a time-much like Bell's ordinary long distance toll (MTS) customers. ${ }^{126}$ Under the Resale and Shared Use decision, TELPAK rates encouraged private line competition, smce the competing carriers could pass on the cost savings of bulk use to small

1026 (1975). The Commission required the independent local telephone companies to do the same. 46 F.C.C.2d at 437.

119. Domestic Communications-Satellite Facilities, 34 F.C.C.2d 1, 35 F.C.C.2d 844, 38 F.C.C.2d 665 (1972).

120. 35 F.C.C.2d at 847.

121. 38 F.C.C.2d at $676-77$. This restriction ended on July 23,1979 . Competitive Carrier Rulemaking, 77 F.C.C.2d at 320 n.16. The Commission was concerned that AT\&T would deter entry in the satellite private line market by using satellites for monopoly traffic as well as for private line services. In that way, AT\&T would be able to use its satellites to their full capacity froin the start, while competitors necessarily would begin operating with excess capacity. Moreover, the Commission would be largely unable to detect any subsidization that AT\&T might provide to its competitive services through an improper allocation of costs between the competitive and monopoly services. 34 F.C.C.2d at 52.

122. Telenet Communications Corp., 46 F.C.C.2d 680 (1974); Graplınet Sys., Inc., 44 F.C.C.2d 800 (1974); Packet Communications, Inc., 43 F.C.C.2d 922 (1973).

123. 43 F.C.C.2d at 922.

124. Id. at 925 .

125. Resale and Shared Use, 60 F.C.C.2d 261 (1976), (Report and Order) reconsidered, 62 F.C.C.2d 588 (1977) (Memorandum Opinion and Order), aff'd sub nom. AT\&T v. FCC, 572 F.2d 17 (2d Cir.), cert. denied, 439 U.S. 875 (1978).

126. 60 F.C.C.2d at 297; see Breyer, supra note 71, at 49. 
users. $^{127}$

The Execunet $I^{128}$ decision in 1977 opened wide the door to competition against Bell's MTS and WATS services. MCI's Execunet service, first proposed in 1975, is primarily a toll service rather than a private line service. With the service a customer can use any telephone to call an MCI office and be connected through MCI's microwave system with any telephone in a number of different cities served by the firm. None of the plant used in the course of a call "is dedicated to the use of a particular customer during any specified time; rather it is available upon demand." 129

Initially, the FCC rejected the Execunet tariff because in Specialized Common Carriers it had authorized MCI only to offer private line services. ${ }^{130}$ The court of appeals reversed the FCC's holding ${ }^{131}$ on the ground that the Commission had not deterinined affirmatively that the public convenience and necessity required that the new entrants be restricted to providing only such services:

[T] he Commission did not perhaps intend to open the field of common carrier commumications generally, but its constant stress on the fact that specialized carriers would provide new, innovative, and hitherto unheard-of communications services clearly indicates that it had no very clear idea of precisely how far or to what services the field should be opened. ${ }^{132}$

In the wake of that decision, the FCC launched an inquiry addressing the issue of whether competition im the MTS and WATS markets serves the public imterest. ${ }^{133}$ In the meantime, this competition has been

127. The FCC earlier had struck down the restrictions that Bell had placed on the sharing of TELPAK and ordered Bell to extend sharing privileges to all private lime customers. The court of appeals reversed the Commission as to the latter part of its decision on the ground that it had not found that the extension of such privileges would be just, fair, and reasonable. TELPAK Tariff Sharing Provisions, 23 F.C.C.2d 639 (1969), 23 F.C.C.2d 606 (1970), aff'd in part and rev'd in part sub nom. AT\&T v. FCC, 449 F.2d 439 (2d Cir. 1971). The Commission tailored its Resale and Shared Use decision to meet that requirement. 60 F.C.C.2d at 289, 298-303, 572 F.2d at 23-24. Bell reacted to the Resale and Shared Use decision by filing a tariff revision elimmating TELPAK. See Amendments Hearings, supra note 18, at 1114 (statement of AT\&T). The FCC, over the objections of the Justice Department and a number of users, approved the revision, and the court of appeals declined to review the agency's order. AT\&T, Long Lines Dep't, 64 F.C.C.2d 959 (1977), rev'd sub nom. Aeronautical Radio, Inc. v. FCC, No. 77-1333 (D.C. Cir. June 24, 1980) (slip op.), rev'd on rehearing for nonreviewability (D.C. Cir. Nov. 5, 1980) (slip op.).

128. MCI Telecommunications Corp., 57 F.C.C.2d 271 (1975) (Menorandum Opinion and Order), 60 F.C.C.2d 25 (1976) (Decision), rev'd, 561 F.2d 365 (D.C. Cir. 1977), cert. denied, 434 U.S. 1040 (1978).

129. 60 F.C.C.2d 25, 26 n.1 (1976) (Decision).

130. 57 F.C.C.2d 271 (1975) (Memorandum Opmion and Order), 60 F.C.C.2d 25 (1976) (Decision).

131. 561 F.2d 365 (D.C. Cir. 1977), cert. denied, 434 U.S. 1040 (1978).

132. $561 \mathrm{~F} .2 \mathrm{~d}$ at 379.

133. MTS and WATS Market Structure, 67 F.C.C.2d 757 (1978) (Notice of Inquiry and Pro- 
growing at a fast rate. ${ }^{134}$

Overall, the FCC's response to recent changes in the telecommunications industry has been progressive, but it has been incomplete, with poorly-defined objectives and frequent errors. Well-considered legislative reform would greatly improve the regulatory scheme.

\section{III \\ Legislative Proposals Concerning CoMpetition in TELECOMMUNICATIONS}

The recent history of the telecommumications mdustry shows a probably irreversible trend toward competition and open entry. Although its decisions have not been uniformly procompetitive, in general the FCC appears willing to risk losing the possible economies of scale existing in the industry ${ }^{135}$ in order to obtain the benefits of spe-

posed Rulemaking), 73 F.C.C.2d 222 (1979) (Supplemental Notice), 77 F.C.C.2d 224 (1980) (Second Supplemental Notice).

134. See note 8 and accompanying text supra.

AT\&T did not stand idle after Execunet $I$. When the Supreme Court denied eertiorari, the company discontmued its interconnection with $\mathrm{MCI}$ for Execunet service, arguing that under Bell Tel. Co. of Pennsylvania v. FCC, 503 F.2d 1250 (3d Cir. 1974), cert. denied, 422 U.S. 1926 (1975), its interconnection obligation was limited to private hine services, and that Execunet $I$ had not altered this. The FCC agreed, but again the court of appeals reversed. AT\&T, 67 F.C.C.2d 1455, rev'd sub nom. MCl Telecommunications Corp. v. FCC (Execunet II), 580 F.2d 590 (D.C. Cir.), cert. denied, 439 U.S. 980 (1978).

135. Although there has been considerable debate between Bell and its competitors on this issue, there is as yet no conclusive proof of operational economies of scale in long distance communications. Waverman, The Regulation of Intercity Telecommunications, in Promoting CompEtITION IN Regulated Markets 223 (A. Phillips ed. 1975). Over the years, Bell has submitted to the FCC a number of studies that claim to show economies of scale, but the FCC has criticized Bell's studies on inethodological grounds. With respect to Bell's most recent submission, the Commission stated:

In summary, we feel that there are significant problems with inodel specification, the data, and the methods of econometric estimation. These difficulties are so substantial that a definitive conclusion concerning either the existence or magnitude of economies of scale in the Bell System cannot be determined from this exhibit. It is possible that econoinies of scale for the entire Bell System either do not exist or are small.

Customer Interconnection, 75 F.C.C.2d 506, 551 (1980) (Second Report) (citations omitted).

The long-run economies of scale that currently seem to exist in long distance telecommunications are actually the savings derived froin centralized planning and the transactional savings from doing business with one's own firm (e.g., an agreement to interconnect between AT\&T's Long Lines Division and a Bell operating company) rather than negotiating with another firm. Waverman, supra, at 223.

Bell argues that centralized planning, which is necessary, for instance, to ensure that there will be enough backup plant to meet peak demand, is made more diffieult by the entry of competition. See Breyer, supra note 71 , at 15 . However, it is $\mathrm{m}$ the best interests of competitors to aid in coordinating the telphone network. Also, the benefits of centralized planning are open to question:

[C]entral planning and control does not necessarily lead to the most efficient system. Implicit in the central planning approach to designing and engineering the telephone network is the assumption that the planners know what is best for the customers. However, in the present era of rapid technological change and computerization of communi- 
cialization. In addition to the advantages of specialization, there may be direct cost savings due to the shift to a competitive market. Market forces should foster greater efficiency, thereby keeping costs and prices down. ${ }^{136}$

Although events already have altered significantly the state of the telecommunications common carrier industry, for the reasons discussed above $^{137}$ it is important that Congress lend direction to the reform of the industry. It seems clear that if Congress does take a stand here, it will be in favor of competition. ${ }^{138}$ Such a choice, however, could have harmful results if not carefully thought out and impleniented. The remainder of this Comment will focus on some of the important questions raised by the prospect of legislation that would widen competition in the telecommunications common carrier industry.

\section{A. Jurisdiction}

State PUC's currently exercise authority over all intrastate telecomunications service, both local and toll. ${ }^{139}$ In contrast, both the House and Senate bills would have given the FCC exclusive authority

cations functions, it is difficult if not impossible for a centralized planning system to detect and respond to the many diverse needs of customers who continually seek to make more efficient use of the telecommunications system.

Customer Interconnection, 75 F.C.C.2d 506, 547 (1980) (Second Report). In short, the benefits of competition could easily outweigh any benefits from centralized planning.

Bell has also argued that significant operating economies of scale will result from the introduction of new technologies such as laser or fiber optics transmission as the density of use mcreases along inajor routes, and that competition might delay the introduction of these technologies. This argument is based on the conclusion that it is not economically feasible to introduce the new technologies until a very higl density of demand-now experienced on only a few routes-exists. Bell argues that splitting the major routes among several suppliers will retard this process. See Breyer, supra note 71, at 14-15; Waverman, supra, at 223-24.

However, given that AT\&T would be able to make a price response when it introduced fiber optics or laser, the delay argument does not hold up. Once adequate overall demand existedeven if met by several carriers-Bell should be able to mstall the new facilities and draw customers away from its competitors by lowering its prices. Alternatively, assuning that the financing could be arranged, one of the competitors could install the facihties to drive out the others, including Bell.

136. C. MCCONNELl, EConomics 45 (6th ed. 1975).

137. See notes 12-19 and accompanying text supra.

138. Consider the statement of Senator Hollings: "Natural monopoly and economy of scale are ideas of the past; competition and diversity are ideas of the future." Amendments Hearings, supra note 18, at 413 (quoted in statement of C. Gus Grant, Southern Pacific Communications Co.).

The only anticompetition legislative proposal-the so-called "Bell bill" (Consumer Communications Reform Act of 1976, H.R. 12323, 94th Cong., 2d Sess. (1976); Consumer Counununications Reform Act of 1978, H.R. 8, 95th Cong., 1st Sess. (1977))-never left the committee. Wall St. J., Feb. 5, 1980, at 48, col. 1. It was not reintroduced after 1977. Amendments Hearings, supra note 18, at 357 (statement of Sharon Nelson, Consumer's Union).

139. Mathison \& Walker, supra note 74 , at 6. 
to regulate intrastate toll service. ${ }^{140}$

Such a change in the jurisdictional scheme is appropriate for several reasons. First, state regulators generally have opposed the introduction of coinpetition into the industry. They see it as a threat to the low cost of local service and toll service along low-density routes, as well as to their own jurisdictional authority. ${ }^{141}$ Thus, leaving state regulators with authority over nonlocal service would be at odds with the goal of establishing a consistently procoinpetitive national policy in the long distance coinmunications field. Second, the imtrastate/interstate distinction is arbitrary; the distinction betwen local and toll services is more meaningful from both a technical ${ }^{142}$ and market point of view. ${ }^{143}$ Finally, many telephone users have been dissatisfied with state regulation due to the disparity between charges for imtrastate and interstate toll calls of the same distance. ${ }^{144}$ If the jurisdictional boundaries were altered, such calls would be treated the same. ${ }^{145}$

An argument in favor of retaming the current jurisdictional boundaries is that if significant competition emerges over intrastate toll routes, state regulators would be in a better position to guard against predatory pricmg by a dominant carrier. ${ }^{146}$ This argument is speculative, however, especially since any new legislation would contain safeguards designed to enhance federal regulators' ability to deal with such anticompetitive behavior. ${ }^{147}$

Assuming that the jurisdictional boundaries will be changed, the remaining question is how the hines between local exchange areas and toll service areas should be drawn. State regulators should have primary responsibility for drawing these lines, since they are in a better

140. See S. $2827 \S 103,126$ CoNG. REC. S7016 (daily ed. June 13, 1980) (amending 47 U.S.C. $\S 152$ ); H.R. 6121 § 2(a) (amending 47 U.S.C. $\$ 201$ ).

141. See Amendments Hearings, supra note 18, at 1322-26 (statement of Edward Larkin, National Ass'n of Regulatory Utility Comm'rs).

142. For example, intrastate toll calls may be routed through other states. Amendinen/s Hearings, supra note 18, at 265 (statement of Charles Zielinski, New York State Public Service Comm'n). Also, while intraexchange service is generally considered a natural monopoly, interexchange (toll) service probably is not. See text accompanying notes $41-45$ supra.

143. Amendments Hearings, supra note 18, at 241 (statement of Henry Geller, Department of Commerce).

144. Id. at 265 (statement of Charles Zielinski, New York State Public Service Comm'n).

145. Under a rate deaveraging program, charges for calls of equal distance would still vary, but those variations would be due to actual cost differences, not to differing regulatory schemcs. See text accompanying notes 179-87 infra.

146. Since the states would continue to have primary jurisdiction over the company's books, records, and accounts, as well as perhaps a greater capability to examine the operations of a particular company than the FCC, whose responsibility would be nationwide, state commissions might be better protectors against predatory pricing by the telephone companies if significant competition for intrastate long distance busmess emerges. Amendinen/s Hearings, supra note 18, at 265-66 (statement of Charles Zielinkski, New York State Public Service Comm'n).

147. See text accoinpanying notes 194-241 infra. 
position to weigh the communities of interest and economic ties between adjacent areas. However, they should not be permitted to expand their jurisdiction artificially. The House bill would not have imposed such a limit; in essence, it would have left the definition of local exchange areas to the states. ${ }^{148}$ The Senate bill's approach was preferable. It would have retained the existing configurations, but required that any reconfiguration by a state commission not impede the FCC's performance of its duties or be inconsistent with the bill's provisions or purposes. ${ }^{149}$

\section{B. Separations}

As discussed above, ${ }^{150}$ under current station-to-station principles, separations payments have been increasingly used to subsidize intraexchange telephone services. ${ }^{151}$ There are several probleins with this systern. First, current separations procedures distort economic incentives at the local level, leading to inefficiencies and slowing adaptation to technological change. ${ }^{152}$ This stems from the nature of the present system: Out of total interexchange revenues, each participating carrier receives an amount that covers its operating costs allocable to interexchange calls and a return element based on its share of all carriers' total expenses and investments allocable to interexchange service. ${ }^{153}$ This second element, which has grown artificially over the years, reduces the participants' incentives to develop and use cost-saving technologies and inethods of operation. ${ }^{154}$ In addition, although separations procedures undoubtedly have helped to fulfill the universal service mandate by subsidizing local service, there is no evidence that

148. H.R. 6121 § 2(a) (amending 47 U.S.C. \& 201).

149. S. $2827 \S 224,126$ CONG. REC. S7022-23 (daily ed. June 13, 1980) (adding 47 U.S.C. $\$ 226)$. To the extent that a reconfiguration failed these tests, the FCC itself could redefine the exchange area. In that event, an "interested party" could petition the Commission, which would then consult with the affected state and the joint board of state and federal regulators established under $\$ 222(\mathrm{~d})$ to administer separations procedures. Id.

150. See text accompanying notes 88-89 supra.

151. See Amendments Hearings, supra note 18, at $963^{\prime}$ (statement of Dale Hatfield, National Telecommunications and Information Administration (NTIA)); id. at 1008-09 (statement of Raymond Dujack, FCC); id. at 1244 (statement of GTE). See also Breyer, supra note 71, at 25-28.

152. See Amendments Hearings, supra note 18, at $245 \mathrm{n} .7$ (statement of Henry Geller, Department of Commerce); id. at 963 (statement of Dale Hatfield, NTIA).

153. MTS and WATS Market Structure, 77 F.C.C.2d 224, 227 (1980).

154. Since costs allocable to interexchange service are reimbursed on a dollar-for-dollar basis, the first element is neutral with respect to changes in economic efficiency: a carrier neither gains nor loses when it reduces its interexchange costs. However, any innovation that reduces a carrier's total interexchange costs reduces that carrier's share in the second element of separations, thus penalizing the carrier for its added efficiency. It still may be economically sound for a carrier to reduce intra exchange costs through innovation, but any savings that it realizes will be partly offset by reducing the second element of the separations scheme if the imnovation also reduces total inter exchange costs. 
the mandate cannot be fulfilled as efficiently through other methods, such as external subsidies, that would not distort prices and economic incentives. ${ }^{155}$ Finally, separations is already an unwieldy process involvimg complex negotiations among multiple parties; adding a large number of participants whose interests conflict with Bell's would only further impede the process. ${ }^{156}$

Both Senator Hollings' bill and Representative Van Deerlin's bill would have replaced the separations process with a two-element substitute: 1) an access charge designed to compensate local exchange carriers for the costs of providing local interconnection to long distance carriers, ${ }^{157}$ and 2) a contribution element designed to minimize the disruption associated with the elimination of separations. ${ }^{158}$ While the retention of the contribution element would introduce an economic distortion, the bills would limit its effeet by placing a ceiling on that eleinent and phasing it out over time. ${ }^{159}$

Such a scheine would be desirable, since it would elininate disparate treatment of different carriers, ${ }^{160}$ and the eventual elimination of

155. Amendments Hearings, supra note 18, at 239-40, 245, 247 (statement of Henry Geller, Department of Commerce).

156. Id. at 245 n.7 (statement of Henry Geller, Department of Commerce). Before the allocation of separations payments in accordance with the formula outlined above, the parties involved must agree on the percentage of long distance revenues to be distributed as separations payments. This amount is determined through negotiations among the FCC, the states, Bell, and the independents. See id. at 963 (statement of Dale Hatfield, NTIA). Under current separations procedures, most of the carriers competing with Bell make no payments and therefore do not participate in the process at all. But see Exchange Network Facilities for Interstate Access, 7I F.C.C.2d 440 (1979) (providers of MTS/WATS-like services agree to pay separations). If present separations procedures were to be continued in an era of increasing new entry, competing carriers eventually would have to make payments and participate in negotiations. See note 160 infra. Under the separations schemes in the proposed legislation, this negotiation process would be eliminated.

157. H.R. 6121 §3(d) (adding 47 U.S.C. § 233); S. 2827 § 222(d), 126 CoNG. REC. S7022 (daily ed. June 13, 1980) (adding 47 U.S.C. $\$ 222$ ). The access charge would cover both direct costs and the portion of overhead costs allocable to interexchange service. Both the access charge and the contribution element would have been applied uniformly to all carriers. Id.

158. H.R. 6121 \&3(d) (adding 47 U.S.C. § 233); S. 2827 \$ 222(d), 126 CONG. REc. S7022 (daily ed. June 13, I980) (adding 47 U.S.C. $\S 222$ ).

159. H.R. 6121 would have eliminated the contribution element over a six-year period while allowing access charges to increase as costs rose. H.R. $6121 \S \S 3$ (a) (adding 47 U.S.C. $\S 231$ ), 3(d) (adding 47 U.S.C. $\$ 233$ ). S. 2827 would have established a formula under which access charges plus the contribution element could not exceed the amount transferred through separations in 1980 minus $\$ 500$ million, and under which any increase in access charges would have to be offset by a decrease in the contribution element. The result would have been that the contribution element would be eliminated when access charges equaled the 1980 separations amount minus $\$ 500$ million. Access charges could continue to rise past that point. S. $2827 \S 222$ (d), 126 CONG. REC. S7022 (daily ed. June 13, 1980) (adding 47 U.S.C. § 222).

160. Under present separations practices, regular long distance carriers (Bell and independent) participate fully, providers of MTS/WATS-like services participate to a limited extent (paying proportionately Iess than the regular carriers), see Exchange Network Facilities for Interstate Access, 71 F.C.C.2d 440, 445-46 (1979), and other carriers do not pay any separations at all. Because the various types of carriers are treated differently under current practices, the FCC has 
the contribution element would provide local exchange companies with a greater incentive to adopt cost-saving operating methods and technology. ${ }^{161}$ The latter effect would help counteract the loss of the contribution currently provided through separations. In the words of one observer:

[S]uccessfully weaning the local exchange industry from A.T.\&T.'s dole will promote a resurgence of that imdustry fron the stagnant backwater in which it has steeped for 50 years into a vibrant, turning tide that will significantly contribute to achieving an urban-rural parity in the diversity, availability and usefulness of telecommunications services. ${ }^{162}$

The threat to universal service and reasonable local rates could be mitigated further through a wider use of measured local service ${ }^{163}$ and through contmuation of the Rural Electrification Administration's lowinterest loan program for qualified exchange companies. ${ }^{164}$ The risk of upward rate pressure im certam local exchange areas would remain, but it would be reasonable for Congress to conclude that this threat would be outweighed by the benefits of competition.

The growing array of widely differmg service offerings raises the issue of which carriers should be required to pay access charges. Both bills would require all those who directly or imdirectly ${ }^{165}$ interconnect with the local switched network to pay both elements of the access charge. ${ }^{166}$ This approach would be equitable, since it would ensure that everyone using local exchange networks supported them. However, the system may present some practical problems, since it may be difficult to police indirect access. ${ }^{167}$

Given the proposed substitution of access charges for the current

found it necessary to attempt to develop a new formula that will not raise the problem of "unjust or unreasonable discrimination" under 47 U.S.C. $\$ 202$ (a) (1976). See MTS and WATS Market Structure, 77 F.C.C.2d 224, 230-31 (1980).

161. Amendments Hearings, supra note 18, at 1009 (statement of Raymond Dujack, FCC). Since the proposed schemes would retain the dollar-for-dollar reimbursement element and drop the "return" element, they would (after the phase-out is complete) be truly neutral with respect to reductions in costs due to interexchange service, as contrasted with the current disincentive. Moreover, carriers would stand to reap the full benefit of any cost savings that they might achieve with respect to intraexchange service.

162. Id. at 950 (statement of William McGowan, MCI Telecommunications Corp.).

163. Id. at 223 (statement of Charles Brown, AT\&T). Also known as usage sensitive service, measured local service is billed not at a fiat rate, but rather aceording to the amount of usage. The advantage of measured local service is that it allows subscribers to avoid expensive regular service but still have a telephone available for important calls.

164. Id. at 246 (statement of Henry Geller, Department of Commerce).

165. Indirect access can be obtained through a Private Branch Exchange-a private switchboard.

166. S. 2827 § 222(d), 126 CoNG. REC. S7022 (daily ed. June 13, 1980) (adding 47 U.S.C. § 222); H.R. $6121 \S 3$ (d) (adding 47 U.S.C. § 233). See also H.R. REP. No. 1252, Part 1, 96th Cong., 2d Sess. 79 (1980).

167. See Amendments Hearings, supra note 18, at 967 (statement of Roy Bahnson, GTE). 
separations process, principles of economic efficiency would also require that those who could interconnect, but do not, also pay the transitional contribution element. ${ }^{168}$ Unfortunately, neither of the proposed bills would have included such a requirement. Not requiring those who could, but do not, access the local system to pay a contribution would create an "inefficient incentive to find ways not to connect to the local exchange, regardless of whether the local exchange is the most efficient and cheapest alternative," 169 leading to an inefficient allocation of resources. To the extent that local distribution markets are natural monopolies, any duplication of networks will necessarily be wasteful. ${ }^{70}$ More important, such a migration of major users away from the existing local network would leave small users, especially residential users, bearing a much higher portion of the costs of maintaining local networks than they do now. ${ }^{171}$

Requiring a contribution from those who have no use for the exchange network-for example, certain data-service carriers-would be unfair, and the bills did not provide for such payment.

The two bills liad different provisions as to the administration of the access charges. The Van Deerlin bill called for administration by a joint board of federal and state regulators for six years, and then by the FCC. ${ }^{172}$ Under the Hollings bill, the states would administer small local exchange carriers, while large exchange carriers would be under the autlority of a joint state-federal board. ${ }^{173}$

There is a tension between the desire to give the states as much authority over local excliange carriers as possible and the desire to prevent them from subverting the regulatory scheme by setting access cliarges too ligh. It is important to give the states considerable authority here since, in the words of a federal observer, they "are in a better

168. A carrier seeking a backup for its local distribution system might face a choice of interconnecting with existing local facilities, building its own backup equipment, or doing without a backup. If the carrier were to choose either to build its own facilities or to forego a backup, it would be one which "could interconnect, but did not," and thus should be subject to payment of the transitional contribution element.

169. Amendments Hearings, supra note 18, at 1013 (statement of H. Milton Stewart, Standard Telephone Co.). Consider the example described in note 168 supra. Under either of the proposed bills, the carrier would pay the not-economically-justified contribution element only if it chose to interconnect with existing facilities. Levying this noneconomic charge would skew the carrier's choice away from local interconnection.

170. See text accompanying notes 69-73 supra.

171. H.R. ReP. No. 1252, Part 1, 96th Cong., 2d Sess. 72 (1980).

172. H.R. 6121 \& 3(a) (adding 47 U.S.C. \& 231). The joint board was to have been created especially for this purpose.

173. S. 2827 § 222(d), 126 CoNG. REC. S7022 (daily ed. June 13, 1980) (adding 47 U.S.C. $\S 222$ ). A local exchange carrier serving inore than 50,000 stations (subscribers) would be a large carrier, and would thus be under the jurisdiction of the joint board, while one serving less than 50,000 stations would be a sinall carrier, under state jurisdiction. 
position to examine and respond to the operations and behavior of the individual operating companies." 174 On the other hand, states may tend to set access charges artificially high in order to subsidize local operating companies at the expense of interstate carriers, and to keep local telephone rates down im their areas. By economically penalizing those who interconnect as agamst those who do not, settimg artificially high access charges would aggravate the dangers and economic distortions that would result from applying the contribution element only to those who actually interconnect.

Although the problem of states overcharging carriers for interconnection is a real concern, it is not necessary to restrict state participation in the process as much as the Van Deerlin bill would have done. The danger that the states would permit inordinately high charges for exchange access would be offset at least in part by local pressure from heavy users of interexchange services. ${ }^{175}$ Also, the developinent of widespread alternatives to local exchange access eventually would vitiate the ability of state regulators to extract a contribution greater than actual costs. ${ }^{176}$ And permitting the FCC to review state decisions as to access charges, as the Hollings bill would have done, ${ }^{177}$ would safeguard adequately against innroper state behavior.

\section{Interexchange Rate Deaveraging}

Nationwide rate averaging on interstate toll calls has been an accepted method of fulfilling the umiversal service mandate. However, this pricing practice is incompatible with a policy of open entry into interexchange telecommunications markets. In a competitive atmosphere, rate averaging would expose Bell to a loss of business along high-density routes through "cream-skimming" by its competitors. Competitors would enter only the high-density, low-cost markets that Bell was serving at artificially high prices. If Bell were not allowed to "deaverage" its rates and meet the competitors' prices, the competitors would soon be able to capture inost or all of the high-density markets, leaving Bell to serve only low-density routes. Under a rate averaging scheme, communications on low-density routes is priced below cost,

174. See Amendments Hearings, supra note 18, at 964 (statement of Dale Hatfield, NTIA).

175. Id. at 246 (statement of Henry Geller, Department of Commerce).

176. Id. The technology now exists to enable voice-service users to circumvent the local network through the use of rooftop antennas, see id. at 971 (statement of Charles Jones, AT\&T), although it is not yet econounical for them to do so. Data-services carriers are already in a position to provide their own local links. Id. at 692 (statement of Paul Likms, Xerox Corp.); id. at 1517 (statement of Andrew Inglis, RCA American Communications, Inc.).

177. S. 2827 § 222(d), 126 CoNG. REC. S7022 (daily ed. June 13, 1980) (adding 47 U.S.C. $\$ 222$ ). The bill would have required an affected party to show that the state had not complied with the FCC's practices as to regulation of exchange access. 
since those routes are subsidized by the artificially high prices on highdensity routes. ${ }^{178}$ Unless Bell could be released from its averaged prices on the low-density routes, it would be subject to losses on those routes without subsidization froin its previously profitable routes. Since it would be difficult to secure FCC approval of deaveraging under the current regulatory scheine, ${ }^{179}$ a statutory change is appropriate.

Neither Senator Hollings' bill nor Representative Van Deerlin's bill would have openly made such a change. Both retained the type of language that the FCC used to justify rate averaging under the 1934 Act. ${ }^{180}$ However, both bills at least implicitly recognized that deaveraging would take place, since they would have used part of the contribution provided by interexchange carriers to help keep rural toll prices down. ${ }^{181}$ The bills also would have prohibited the pooling of revenues inherent in rate averaging unless the FCC were to find it necessary in order to inaintain quality service in a locality. ${ }^{182}$

The threat posed by deaveraging in conjunction with the proposed legislation, as under the current systein, is that per-unit costs on some low-density routes inight becoine prohibitively high. However, in addition to contributions subsidies, other factors would help to restrict upward rate pressure along rural routes. Toll carriers maintam a longlines network that links the inajor population centers of the country. Calls are routed through this network whenever possible, even if both parties are located in rural areas. Thus, the mam differences in cost between toll calls of a given geographic length are due to variations in the cost of reaching the longlines network. The lines that link local exchanges with this network are called toll connecting trunks, and they represent a sinall portion of the total cost of toll service. ${ }^{183}$

178. See note 89 and accompanying text supra.

179. For a summary of the legal standard applied to petitions for deaveraged rates, see Note, Resale and Sharing of Private Line Communications Systems: A.T.\&T. Restrictions and FCC Regulation, 61 VA. L. REv. 679, 704 (1975). See also Department of Pub. Serv. v. Pacific Tel. \& Tel. Co., 8 F.C.C. 342 (1941).

180. 47 U.S.C. $\$ 202$ (a) provides that "[i]t shall be unlawful for any common carrier . . . to make or give any undue or unreasonable preference or advantage to any particular person, class of persons, or locality . . . ." H.R. $6121 \S 217$ retained this language, while S. $2827 \S 210(\mathrm{c}), 126$ CONG. REC. S7019-20 (daily ed. June 13, 1980) (adding 47 U.S.C. $\$ 208$ ) contained similar language.

Of course, it is likely that regulatory authorities would manifest a different attitude toward requests for deaveraging under procompetitive legislation than they would under the 1934 Act. But the legislation should explicitly require this, rather than leaving it to chance.

181. H.R. 6121 §3(d) (adding 47 U.S.C. § 233); S. 2827 \& 222(d), 126 CONG. REC. S7022 (daily ed June 13, 1980) (adding 47 U.S.C. $\$ 222$ ).

182. H.R. 6121 § 2(a) (amending 47 U.S.C. § 201); S. 2827 § 222(d), 126 CONG. REC. S7022 (daily ed. June 13, 1980) (addimg 47 U.S.C. $\$ 222$ ).

183. See Amendments Hearings, supra note 18, at 247 (statement of Henry Geller, Department of Commerce). 
Deaveraging might stimulate the development of cost-saving technology for such trunks. Moreover, competition on major routes is likely to lead to overall rate reductions, which would result in lower rates for rural users. Thus, under a deaveraged system, price disparities might not be great, and any disruptions would be offset at least in part by increases im overall efficiency.

If upward rate pressure $\mathrm{m}$ some rural areas is significant, there is a risk that routes will become unprofitable and that the carriers serving them will seek to discontmue service. Both bills essentially would have adhered to the present requirement that the FCC find that the public interest would not be harmed before it could permit such a discontinuation of service. ${ }^{184}$ Simce it seems unlikely the FCC would ever make such a finding, the effect would be to force the carrier to continue service. This restriction on exit is consistent with a rate-averaging system, because under such a system losses on some routes can be coinpensated by excess profits on others. However, under a competitive, deaveraged systein, ${ }^{185}$ the high-density routes would yield only a minimum level of profits, while carriers servimg low-density routes would absorb real, uncompensated losses. The regulatory system must allow free exit from unprofitable routes. This does not mean that service need actually be

184. See 47 U.S.C. § 214(a) (1976); H.R. 6121 \& 2(b)(2)(A) (amending 47 U.S.C. § 214); S. $2827 \S 216,126$ CoNG. REC. S7021 (daily ed. June 13, 1980) (amending 47 U.S.C. $\S 214$ ). Under S. 2827 application of the standard would have been discretionary with the FCC, but it is hard to imagime a situation in which the FCC would allow a discoutinuation of service without such a showing. Under H.R. 6121, carriers regulated by the FCC prior to the enactment of the bill would have to show that a discontinuation of service would serve the present or future public convenience and necessity; for carriers brought under FCC regulation by the bill, the burden would be shifted to the Commission.

185. Both bills generally favor competition in long distance service. The Vau Deerlin bill would permit any carrier other than a regulated or dommant carrier to enter markets freely. The only dominaut carrier would be AT\&T; a regulated carrier would be a local exchange carrier that also provides universally available long distance voice service, or an interexchauge carrier that the FCC regulates with respect to the provision of: (a) universally available long distauce service, (b) service in association with AT\&T, (c) service regulated under the 1934 Act until deregulated, or (d) service that the FCC finds is no longer subject to effective competition. See H.R. 6121 \& 2(a) (amending 47 U.S.C. § 201).

The Hollings bill would also permit free entry by carriers other than dominant-regulated (the bill's equivalent of H.R. 6121's "dominant" carriers) or regulated carriers, and even those carriers could enter markets freely if permitted to do so by the Commission (for regulated carriers, entry would be free unless the Commission provided otherwise by rule or order, for dominant-regulated carriers, permission to enter without a certificate of public convenience and necessity could be granted on a case-by-case basis). S. $2827 \$ 216,126$ CoNG. REc. S7021 (daily ed. June 13, 1980) (amending 47 U.S.C. $\$ 214$ ). The dominant-regulated carriers would be the six largest in the country-AT\&T, GTE, United Telecominunications, Inc., Central Telephone and Utilities Corp., Continental Telephone Corp., and Mid-Coutinental Telephone. See id. \$ 205, 126 CoNG. Rec. S7C19 (daily ed. Juue 13, 1980) (amending 47 U.S.C. \& 203). See also New Objections Slow Pace of Communications Rewrite, 38 CoNG. Q. WeEkLY ReP. 1943, I946 (July 12, 1980). A regulated carrier would be one that liad been a recipient under the separations process. S. $2827 \& 205,126$ CONG. REC. S70I9 (daily ed. June 13, 1980) (amending 47 U.S.C. § 203). 
discontinued on any route: The federal government could subsidize the difference between the revenue available on the route and what the lowest bidder would require to service it. ${ }^{186}$ Such a subsidy would be more efficient than that provided by rate averaging ${ }^{187}$ and would be subject to greater accountability. Unfortunately, while the proposed bills anticipated deaveraging, they failed to include the subsidy mechanism that would be necessary to ensure a smooth deaveraging process.

\section{Bell Corporate Structure}

Regulators have long been concerned about the effect of permitting a large regulated firm such as AT\&T to enter adjacent unregulated markets. For its operations in regulated markets, Bell simply calculates its costs and capital investment and submits tariffs sufficient to cover those costs and provide a reasonable rate of return on its investment. ${ }^{188}$ Thus, by allocating disproportionate shares of costs and investment to its regulated operations, Bell could effectively subsidize its competitive operations. The result is that monopoly customers would overpay for services, and other firms operating im unregulated markets would find it difficult or impossible to compete with Bell. If AT\&T were able to drive its competitors out of the unregulated markets, customers im those formerly coinpetitive markets would also suffer.

Cross-subsidization can also take other forms, including transfers of personnel and information from monopoly to competitive services and preferential treatment of a corporate affiliate over its competitors. The regulated carrier may also enjoy advantages, such as reduced cost of capital and a low tax rate, ${ }^{189}$ that give it an edge in the provision of

186. Consider the Commerce Department's proposal:

If, on a particular interexchange route, no carrier is willing to initiate service or to continue to offer interexchange message telephone service at affordable rates, then the Federal regulator would request bids for providing service. For this purpose, the Federal regulator would determine minimum service requirements and would accept the lowest bid consistent with those standards. A fund maintained by the Treasury of the United States, to be known as the Interexchange Telecommunications Compensation Fund, would provide service subsidies where needed. Such sums as necessary to carry out the program would be appropriated to this account on an annual basis.

Amendments Hearings, supra note 18, at 247 (statement of Henry Geller, Department of Commerce).

187. The use of competitive bidding would provide incentives for economic efficiency, in contrast to the rate averaging system, under which a carrier simply computes its total costs for all areas and submits a uniform tariff to cover the total.

The total amount of the subsidies might not be great. As discussed at text accompanying note 183, the differences in unit costs between high- and low-density routes can be overstated. According to a study by the National Telecommunications and Information Administration, it would take approximately $\$ 236$ million to limit rate increases to $10 \%$, and $\$ 100$ million to limit increases to $20 \%$ (under a worst-case analysis, the cost would be $\$ 434$ million and $\$ 236$ million, respectively). Amendments Hearings, supra note 18, at 994-95.

188. Mathison \& Walker, supra note 74 , at 6 .

189. Control Data Corporation has asserted that because of its monopoly rate base, Bell's 
competitive services not derived from greater efficiencies. The result is the same as with predatory pricing: Bell might eliminate competitors that are actually more efficient in their use of resources simply because of its noneconomic cost advantages.

One solution to the problem of cross-subsidization would be to bar Bell from unregulated markets. This was the approach of the 1956 consent decree, which restricted Bell to the provision of regulated communications services, ${ }^{190}$ thus restraming it from entering the data processnig field. ${ }^{191}$ While this solution avoided the threat of cross-subsidization, it was essentially anticompetitive. It removed from the contpetitive markets a dynamic competitor whose integrated structure, while worrisome, might present significant cost advantages. Because of the anticompetitive effect of the decree, and because the boundary between communications and data processing has become nicreasingly unclear, ${ }^{192}$ the FCC recently reevaluated the decree. ${ }^{193}$

In its Second Computer Inquiry decision, the FCC sought to balance the need to regulate AT\&T and the desire to have it participate in the burgeoning data communications market. As the Commission stated: "[T]he general learning on vertical imtegration counsels an effort to find some acceptable middle ground between potential economies of integration derived from more efficient production and lowered transaction costs and potential diseconomies stemming from abuses of special positions made possible by integration." 194 The Commission decided to allow the company to offer services that combine elements of data processing and communications. While thus allowing Bell to enter the unregulated data communications field, the FCC decision imposed on it a structural restriction: Bell must provide all such "enhanced services" through a separate subsidiary. ${ }^{195}$ The Commission held that this restriction was sufficient to deal with the problem of cross-subsidization and to nieet the consent decree requirement that all of Bell's services be "subject to public regulation under the Communi-

effective federal tax rate is only nine percent. H.R. REP. No. 1252, Part 2, 96th Cong., 2d Sess. 21 (1980).

190. See United States v. Western Electric Co., Inc., 1956 Trade Cas. 71,134 (D.N.J. 1956); notes 91-92 supra.

191. See H.R. Rep. No. 1252, Part 1, 96th Cong., 2d Sess. 243 (1980).

192. Anthony Oettinger coined the term "coinpunications" to describe these fields, reflecting their inerger. See Berman \& Oettinger, The Medium and the Telephone: The Politics of Information Resources, in HIGH AND LOW POLITICS: INFORMATION RESOURCES FOR THE 80's, 91 \& $\mathrm{n} .38$ (A. Oettinger, P. Berman \& W. Read eds. 1977).

193. Second Coinputer Inquiry, 77 F.C.C.2d 384 (1977).

194. Id. at 461.

195. See note 7 and accoinpanying text supra. The separate subsidiary requirement also applied to GTE. 
cations Act of 1934."196

For a variety of reasons discussed above, ${ }^{197}$ the Second Computer Inquiry decision should not be considered a final solution; alternatives should be analyzed in the preparation of new legislation.

In examining proposed solutions, another important consideration is the effect that a change in Bell's corporate structure might have on the Justice Departinent's pending antitrust suit agamst that company. ${ }^{198}$ The suit is regarded as "one of the most important antitrust proceedings brought in the last 50 years," 199 and seeks much more extensive structural change than any of the legislative reforms that have been proposed. ${ }^{200}$ According to the House Judiciary Committee:

Because [the legislative] approach to restructuring differs so drastically from that proposed by the Department of Justice, some observers believe it will influence the Court, directly or indirectly, to limit its relief in a unanner consistent with the legislation. Such an impact has been the publicly stated legislative objective of the Bell System. ${ }^{201}$

Alternatively, enactment of legislation that alters the structure of Bell in this manner might lead to a less than satisfactory settlement of the case. $^{202}$

Current reform proposals seek to maximize competition in the rapidly developing new telecommunications markets while keeping a rein on the monopoly carriers. At the same time, the reforms strive to avoid influencing the outcome of the Justice Department's antitrust suit. The following discussion evaluates the alternatives with respect to these key issues.

196. United States v. Western Electric Co., Inc., 1956 Trade Cas. 71,134, 71,137 (D.N.J. 1956); see 77 F.C.C.2d at 493 (1980). Note that although the FCC is bound by the terms of the 1956 consent decree, Congress may ignore it while amending the Communications Act of 1934, since the decree is merely an interpretation of the Act as it existed in 1956.

197. See text accompanying notes 11-19 supra.

198. United States v. AT\&T, No. 74-1698 (D.D.C., filed Nov. 20, 1974).

I99. H.R. REP. No. 1252, Part 1, 96th Cong., 2d Sess. 261 (1980) (letter from House Judiciary Chairman Peter Rodimo to Representative Van Deerlin).

200. See note 10 and accompanying text supra. Legislation that would grant the relief sought in that case is not considered politically acceptable. Consider the statement of Senator Hollings: "When you come to complete divestiture, we have the House side-apparently they can't get sufficient support for that. It's not that we don't know how to write a bill. It's that we don't know how to get one passed." Amendments Hearings, supra note 18, at 1185 .

201. H.R. REP. No. 1252, Part 2, 96th Cong., 2d Sess. 11 (1980).

202. According to the House Judiciary Committee,

Professor [Louis] Schwartz [of the University of Pennsylvania Law School] concluded that if le were confronted with such a bill as a Justice Department official, he would atteinpt to "get out of the pending antitrust suit with a consent decree that looks pretty good (and) doesn't have too obvious a giveaway quality."

Id. at 13. Also, Comptroller General Elmer Staats, in a letter to Cliairman Rodino, said: "An organizational structure enacted into law may infiuence the litigants to reach a compromise settleinent incorporating such structure even where the evidence in the trial might indicate another structure would be preferable." Id. at 35 . 


\section{Accounting Procedures}

Until the Second Computer Inquiry decision, the only tools the FCC had used to combat cross-subsidization by Bell were accounting procedures. These procedures are nearly useless for the task. The FCC simply lacks the resources to monitor the dominant carriers. ${ }^{203}$ In addition, current accounting procedures are not designed to detect crosssubsidies. ${ }^{204}$ While it is generally recognized that current accounting procedures can and should be improved, ${ }^{205}$ it is unreahistic to expect that accounting measures alone will be adequate to deal with the problem of cross-subsidization. ${ }^{206}$ The weaknesses inherent in the accounting process preclude its effective use as an enforceinent tool. ${ }^{207}$

203. See the summary of testimony before the House Subcommittee on Monopolies and Commercial Law:

Mr. Bernard Strassburg [former Chief of the FCC's Common Carrier Bureau] expressed skepticism whether the FCC has the ability to monitor effectively the accounting records of a dominant carrier. Citing the inassive size of the regulated imstitution and the multimillion dollars involved in daily transactions, Mr. Strassburg concluded that the FCC, despite good intentions, has failed to achieve a record "with any distinction" in conducting such monitoring.

H.R. ReP. No. 1252, Part 2, 96th Cong., 2d Sess. 20 (1980).

204. To deal with cross-subsidization, an accounting system must break down the costs of individual services. The accounting system im use today, the Uniform System of Accounts, see 47 C.F.R. §§ 31-33 (1979), ignores costs by service in favor of data conveying an overall financial picture -the rate base, total revenues and costs, total rate of return, and earnings per share. Amendments Hearings, supra note 18, at 1090 (statement of Edward Goldstein, AT\&T).

205. The FCC has proposed a revision of the Uniform System of Accounts. See Revision of the Uniform System of Accounts Used by Telephone Companies, 70 F.C.C.2d 719 (1978) (Notice of Proposed Rulemaking), 44 Fed. Reg. 47,359 (1979) (First Supplemental Notice). See also Amendments Hearings, supra note 18, at 1092 (statement of Edward Goldstem, AT\&T). However, that is not likely to occur within the next several years. Id. at 268 (statement of Charles Zielinski, New York State Public Service Comm'n). In its Second Computer Inquiry decision, the Counmission called for the fully separated subsidiaries of AT\&T and GTE providing enhanced services to maintain separate accounting books. 77 F.C.C.2d at 498.

Senator Hollings' bill did not address this issue, but Representative Van Deerlim's bill would have required the FCC to implement a substantially revised accounting system within two years after enactment. H.R. 6121 § 4(d) (adding 47 U.S.C. $\$ \S 254-255$ ). The new system would allocate costs among the various services, facilities, and products offered by AT\&T and would separate the costs of Bell's regulated activities from those of its unregulated activities.

206. See the summary of testimony by Walter Hinchman, former Chief of the FCC's Common Carrier Bureau, before the House Subcommittee on Monopolies and Commercial Law: "Mr. Hinchman was convinced that even if the FCC's powers and resources to monitor the separate subsidiary were expanded, no accounting methodology could be devised that could ensure a truly arm's length transaction between parent and subsidiary." H.R. REP. No. 1252, Part 2, 96th Cong., 2d Sess. 21 (1980).

207. Consider the statement of Henry Geller of the Department of Commerce:

[T] ] concept of cost in itself is elusive. Historical cost, which is the basis for accounting, is verifiable and objective but, especially in the context of rapidly changing technology, often irrelevant. Future or prospective costs are relevant, but extremely difficult to verify in any objective sense. Moreover, cost allocations [between competitive and monopoly services], where common costs are substantial, inherently lead to a wide degree of discretion and to an exercise in accounting judginent. Such allocations have hittle if any basis in economic or financial theory. Adding the questions of economies of scale only confounds an already difficult problem. We can conclude that the difficulties imherent im the 


\section{Separate Subsidiaries}

To aid in coinbating cross-subsidization, the bills proposed by Senator Hollings and Representative Van Deerlin, like the FCC in its Second Computer Inquiry decision, would have required dominant carriers to form separate subsidiaries in order to operate in unregulated markets. ${ }^{208}$

The proposals varied as to which carriers would be required to form separate subsidiaries. The Van Deerlin bill would impose the restriction only on AT\&T, ${ }^{209}$ the FCC would impose it on AT\&T and GTE, ${ }^{210}$ and the Hollings bill would impose it on those two carriers as well as the four next largest carriers. ${ }^{211}$ The approach contained in Senator Hollings' bill is best. While several of the carriers included hold very small percentages of the national telecommumications market, all of them are very strong in the regions in which they operate. It is in those regions that they are likely to enter competitive markets and

regulated cost-price approach have the unhappy distinction of coinbining unsolvable theoretical problems with substantial practical problems of implemeutation .... Undue rehance upon it will only frustrate our attempts to achieve fair competition. Amendments Hearings, supra note 18, at 253.

208. There are a number of differences between the various separate subsidiary provisions of the Van Deerlin bill, the Hollings bill, and the Second Computer Inquiry decision. As to the scope of the allowable activities that the subsidiary could carry on, Senator Hollings' bill would have permitted it to provide "any telecommunications service, telecommunications cquipment, or informatiou service or . . . any other business incideutal to such activities." S. 2827 \& 224, 126 CoNo. REC. S7024 (daily ed. June 13, 1980) (adding 47 U.S.C. $\$ \$ 226-229$ ). The subsidiary required by the Second Computer Inquiry apparently would be allowed much the saine scope of activity. 77 F.C.C.2d at 767. The Van Deerlin bill was narrower. It would not have allowed the subsidiary to originate mass media services such as electronic news or data retrieval. Panel Votes to Revamp AT\&T, Deregulate Industry But Floor Action Uncertain, 38 CONG. Q. WEEKLY REP. 2167 (Aug. 2, 1980). This would have prevented, for example, the development of an electronic Yellow Pages by Bell. Bell would have been allowed to act only as an intermcdiary between news and data retrieval eutities and subscribers. Id. Also, Bell would have been precluded from offering any cable service through its separate subsidiary or through its local operating companies, as well as any alarm services. H.R. 6121 §2(d) (adding 47 U.S.C. $\$ \S 218-220$ ).

In a different sense, both bills' separate subsidiary requirements would have been more farreaching than that in the Second Computer Inquiry decision. The FCC decision would only require Bell to provide enhanced services through its separate subsidiary. The Hollings and Van Deerlin bills, on the other hand, essentially would deregulate any market subject to effective coinpetition, including basic service markets. To operate in any of those markets, Bell would have to use the separate subsidiary. See H.R. 6121 § 2(a) (amending 47 U.S.C. \$ 201); S. 2827 § 205 , 126 CONG. REC. S7019 (daily ed. June 13, 1980) (amending 47 U.S.C. $\$ 203$ ), $\$ 207$, 126 CONG. REC. S7019 (daily ed. June 13, 1980) (amending 47 U.S.C. \$ 205), \& 224, 126 CONG. REC. S7022-24 (daily ed. June 13, 1980) (adding 47 U.S.C. $\$ \$ 226-229$ ).

209. H.R. 6121 \& 2(a) (amending 47 U.S.C. $\$ 201$ ).

210. 77 F.C.C.2d at $467-70$.

211. Those carriers are United Telecommunications, Continental Telephone, Central Telephone and Utilities, and Mid-Continent Telephone. Under the Hollings bill, the FCC could modify this list as it saw fit. S. $2827 \S 205,126$ CoNG. REC. S7019 (daily ed. June 13, 1980) (amending 47 U.S.C. \& 203). 
their considerable local market power thus poses a significant threat to competition.

The various proposals differed significantly in the amount of separation each required. The Hollings bill would have demanded substantial separation, as did the FCC im its decision. ${ }^{212}$ Under the Hollings bill, the subsidiary would be phased in over a ten-year period, after which it would be responsible for its own manufacturing and research and development activities. The subsidiary could not share personnel, officers, or property with the parent conipany. The subsidiary would maimtam separate books and prepare federal financial reportimg statements as though it were a publicly held corporation. The parent could not disclose to the subsidiary commercial inforination that would afford it an unfair competitive advantage unless the parent made the $\mathrm{m}$ forination generally available at the same time on nondiscriminatory terms. The FCC would be permitted to innose additional restrictions on the relationship between the parent and subsidiary if it deemed it necessary. ${ }^{213}$

The Van Deerlin bill required significantly less separation. For instance, under the House bill the parent's and subsidiary's boards of directors could have one inember im common. Also, management employees could rotate between the companies, and the FCC could not modify the scheme to require broader separation between the dommant carrier and its subsidiary. ${ }^{214}$

Here again the Hollings approach is the soundest. The purpose of requiring a separate subsidiary is to make the relationship between the regulated and unregulated portions of the company more visible. ${ }^{215}$ Provisions such as that permitting the rotation of management personnel, which would impair that visibility and obscure the flow of information, should be kept to a minimum. Thus, complete separation should be the objective of any legislative proposal. Moreover, in a dynamic field like the telecommumications industry, it is imperative that the FCC be given authority to adjust the separations standards to deal with unexpected problems as they arise. ${ }^{216}$

The key question with respect to the separate subsidiary approach

212. For a description of the separation requirements of the Second Computer Inquiry decision, see note 7 supra.

213. S. 2827 § 224, 126 Cong. Rec. S7022-24 (daily ed. June 13, 1980) (adding 47 U.S.C. $\S \S 226-229)$.

214. See H.R. Rep. No. 1252, Part 2, 96th Cong., 2d Sess. 16-17 (1980).

215. See note 218 and accompanying text infra.

216. The Department of Commerce, while generally in favor of the provisions of H.R. 6121, argued that the FCC " 'should retain the flexibility to take further actions or to modify specific requirements [of separation] on the basis of experience or changed circumstances." "H.R. REP. No. 1252, Part 2, 96th Cong., 2d Sess. 17 (1980). 
is how well it succeeds at striking the balance between the desire for maximum efficiency and the need to regulate the dominant carriers. With respect to maximizing efficiency the approach seems to be effective as the integration benefits to be sacrificed are not unduly great. This conclusion is evidenced by the fact that several large common carriers not affected by any legal order already have initiated reorganizations between their coinpetitive and monopoly operations. ${ }^{217}$

On the other hand, there is considerable doubt whether requiring even a fully-separated subsidiary would be sufficient to curb cross-subsidization. While such a requirement enhances the visibility of dealings between a carrier's monopoly and competitive operations, it does not limit the carrier's mcentives to cross-subsidize. ${ }^{218}$ Since the two companies have the same ownership, any benefit to one will also benefit the other. To the extent that the carrier can allocate joint costs disproportionately to the monopohstic parent, for instance, it will do so. Thus, the effectiveness of the separation concept ultimately depends on the dubious safeguards provided by accounting. Even with increased visibility and separate account books, the FCC's monitoring will be of limited effectiveness. ${ }^{219}$

Given that the separate subsidiary approach has serious limitations as a means of preventing predatory pricing, it is important to inquire whether the approach will fulfill the objective of noninterference with the antitrust suit against AT\&T. Both the Hollings and Van Deerlin bills attempted to deal with this problem through the use of "savings clauses" that specifically expressed Congress' neutrality as to all pending antitrust suits. 220 The clause contained in the House bill incorporated language suggested by the Justice Department and by House Judiciary Chairman Rodino, and the Justice Department took the position that passage of the House bill, at least, would not interfere with the suit. ${ }^{221}$

However, most antitrust experts feel that legislation containing

217. Those carriers are United Telecommunications, Continental Telephone, and Central Telephone. Second Computer Inquiry, 77 F.C.C.2d at 472.

218. See the statement of Assistant Attorney General Litvack in a letter to Chairman Harley Staggers of the House Commerce Committee:

[A] requirement of separate subsidiaries cannot eliminate the incentive of such subsidiaries to discriminate in favor of their affiliates or of AT\&T to seek to circumvent regulatory constraints on its behavior. A more effective means to remove both the incentive and the ability to engage in anti-competitive behavior is some form of divestiture-which, of course, is the objective of the government's AT\&T case.

H.R. ReP. No. 1252, Part 2, 96th Cong., 2d Sess. 16 (1980).

219. Since the allocation of jomt costs between monopoly and competitive services is largely discretionary, there is a serious question as to how much separate accounting books would help. See H.R. Rep. No. 1252, Part 2, 96th Cong., 2d Sess. 38 (1980).

220. H.R. 6121 § 9; S. 2827 § 506, 126 Cong. REc. S7031 (daily ed. June 13, 1980).

221. H.R. ReP. No. 1252, Part 1, 96th Cong., 2d Sess. 82 (1980). The Justice Department's 
limited structural modifications of Bell's structure would inhibit the district court im prescribing structural relief, becase a judge handling such a suit has a duty to consider such congressional action:

Professor Thomas Kauper of the University of Michigan Law School, who was head of the Antitrust Division at the time the pending AT\&T case was filed, . . . noted that as a "purely technical, legal matter, the savings clause may adequately express" the intention of Congress not to have any negative impact on the pending [litigation]. "But a judge in an antitrust case cannot wholly ignore policy judgments reflected in the legislation. Nor could he or she ignore structural changes made in response to the legislation, particularly in fashioning relief."222

The judge must fashion an appropriate remedy on the background provided by the structure of the industry and in view of congressional intent. Either of the proposed bills necessarily would affect that background. Thus, the separate subsidiary approach would be effective in efficiency and competition, but would be meffective in regulating dominant carriers and would imterfere with the Justice Department's antitrust suit against AT\&T.

\section{Alternative Approaches}

The weaknesses of the separate subsidiary approach provide an impetus for examining alternative approaches to these problems. One alternative is to draft legislation that does not rely on corporate separation to inhibit anticompetitive behavior by Bell. This was the approach favored by Peter Rodino, the Chairman of the House Judiciary Coinmittee. He proposed that the Van Deerlin bill be revised so that it not affect the structure of Bell or lift the 1956 consent decree. ${ }^{223}$ The practical effect of such a revision would be to turn the bill into a deregulation bill for the rest of the industry.

Such a plan would not in itself affect the Justice Department suit, since it would not modify the structure of the company. One problem with this approach is that it ignores the effect of the Second Computer Inquiry decision. Atlhougl that decision would effect narrower changes than would the proposed legislation, it is quite similar and it could be expected that AT\&T would use the decision in arguing against

stance apparently is premised on the view that it can establislı violations not "dealt with" in tlee proposed legislation. See H.R. REP. No. 1252, Part 2, 96th Cong., 2d Sess. 12 (1980).

222. H.R. Rep. No. 1252, Part 2, 96th Cong., 2d Sess. 13 (1980). Among those taking a similar position are William Saxbe, Attorney General when the suit was filed, and Professor Scliwartz of the University of Pennsylvania School of Law. Id. at 12-13. Professor Schwartz "testified that a court which 'put its head in the sand' and ignored a congressional enactment permitting AT\&T's conglomeration "would be violating its duty"." Id. at 13.

223. H.R. REP. No. 1252, Part 1, 96th Cong., 2d Sess. 262 (1980). Rodino has argued that Bell's bargaining power in the Justice Department suit will be improved if new legislation would authorize its entry into previously forbidden markets. Id. at 261. 
divestiture in inuch the same way that it would use the legislation itself. $^{224}$ Although FCC action probably would mean less to the court than congressional action, the court is obligated to consider any changes in the structure of the company as well as of the industry itself. 225

With respect to fostering competition and regulatimg the dominant carriers, the Rodino approach would amount to legislative maction. Thus, the question of what markets AT\&T could enter and how it would be prevented from cross-subsidizing would be settled by the combined outcomes of the Second Computer Inquiry and the antitrust suit of the Justice Department. As discussed above, ${ }^{226}$ this is not a satisfactory solution. While the Justice Department action might eventually reach a satisfactory conclusion, in the meantime a reversal of the Second Computer Inquiry decision would leave Bell wholly barred by the 1956 decree from the burgeoning data commumications market, an unnecessarily anticompetitive result. ${ }^{227}$

Perhaps a better proposal for avoiding interference with the Justice Department's suit is to make the structural changes embodied im the legislation provisional, pending the outcome of the suit. This solution is one of several that were considered by the House Subcommittee on Monopolies and Commercial Law. ${ }^{228}$ Such a plan would combime the advantages of allowing the antitrust action to proceed unimpeded while still ensuring much-needed reforn of the telecommunications industry.

The Comptroller General suggested that Bell's equity participation in the subsidiary should be restricted to forty-nine percent or less. ${ }^{229}$ This would effectively restrict the incentive to cross-subsidize; to the extent that the carrier loaded joint costs disproportionately on itself, for example, it would be funneling money to outsiders and subjecting its managers to shareholders' derivative suits. At the same time, some of the integration benefits that might be sacrificed by such drastic remedies as divestiture could be retained. The other participants in the ven-

224. See H.R. ReP. No. 1252, Part 2, 96th Cong., 2d Sess. 12 (1980).

225. See Telecommunications Bill Appears Trapped by Logjam But Maneuvering Continues, 38 CONG. Q. WeEkLY ReP. 2613 (Aug. 30, 1980).

226. See notes 11-19 and accompanying text supra.

227. The exclusion of Bell from the specialized services markets is consistent with the view of the Justice Department that the 1956 decree should not be modified, and that the issue of modification should be addressed by the court that entered the decree and has retained jurisdiction over it rather than by Congress. H.R. REP. No. 1252, Part 2, 96th Cong., 2d Sess. 15 (1980). However, due to the pendency of the present suit, that court probably would not modify the 1956 decree now. Thus, the decree's now artificial restriction on Bell's entry into the hybrid markets would be continued indefinitely.

228. See H.R. Rep. No. 1252, Part 2, 96th Cong., 2d Sess. 23 (1980).

229. See id. at 31-32. 
ture presumably would bring their expertise to bear on the enterprise. ${ }^{230}$

Perhaps the major drawback of this proposal is that it would be a step into the unknown. While the FCC has considerable experience in the use of fully-owned separate subsidiaries as a regulatory tool, ${ }^{231}$ it has relatively little experience in the limited-equity approach. However, in one previous instance, the FCC einployed a very similar analysis and remedy. The participants in a domestic communications satellite venture sought to restructure the organization so as to give IBM a fifty-five percent imterest and voting control and to leave Colnmunications Satellite Corporation (Comsat) holding a forty-five percent interest. ${ }^{232}$ The Commission rejected the proposal largely because it believed that the structure would not allow Comsat a full opportunity to apply its satellite expertise to the undertaking, but also because it feared that Comsat's and IBM's busmess ties with AT\&T might prevent it from being truly competitive. ${ }^{233}$ In 1977 the parties received approval of a proposal that gave Aetna Casualty and Surety Company a degree of control and potential ownership equal to that of the otlier owners. ${ }^{234}$ Although the results of this action are not yet clear, it imdicates that the limited equity approaclı can be workable and palatable to business.

\section{Conclusion}

To sum up, entry by Bell into the data processing communications markets is an attractive policy if Congress can ensure that this would not interfere with the government's pending suit against Bell and that Bell would compete fairly im the unregulated markets. The best approach to the first problem is to make the legislation's structural changes provisional, pending a final decision or settlement of the case. With respect to the second problem, the Comptroller General's limited

230. The FCC, of course, would have to screen prospective participants to offset the danger of oligopolistic behavior in the coinpetitive markets involved. For example, a subsidiary of Bell owned in part by IBM would not be an attractive new competitor. See text accompanying note 233 infra.

231. See H.R. Rep. No. 1252, Part 2, 96th Cong., 2d Sess. 33-34 (1980).

232. CML Satellite Corp., 51 F.C.C.2d 14 (1975).

233. Id. at 37.

234. Satellite Business Sys., 62 F.C.C.2d 997 (1977). Each of the three parties would contribute equally in the pre-operational phase of the venture, but Aetna's equity interest would be limited to $15 \%$, the balance consisting of convertible subordinated notes guaranteed by IBM and Comsat. Nevertheless, Aetna would exercise the same degree of control over the venture during this phase as the other parties. When the systein became operational, Aetna could become a full one-third partner by converting its notes into an equity interest, or could take payment of its notes in the form of a 15-year subordinated unguaranteed debt obligation. In the latter case, voting power would shift accordingly, but IBM and Comsat would continue to hold equal interests, and Aetna would retain its $15 \%$ equity interest and voting power. Id. at 1002. 
equity approach to corporate separation seems especially promising. If that proves not to be workable, then the wholly-owned separate subsidiary mechanism, with full separation between the monopoly parent and the competitive subsidiary, also offers hope. In either event, the FCC should be given authority not only to monitor the financing of the new company, but also to scrutinize its ongoing operations with an eye to modifying the degree of separation between it and AT\&T when appropriate.

\section{CONCLUSION}

It should be clear that congressional guidance is needed here. Technological changes have called into question traditional theories of regulation of the telecoinmunications industry, but the FCC and the courts have not been able to adapt to these changes. New legislation would give them a clean slate with which to work. The complexity of the issues presents a formidable but by no means insurmountable barrier to Congress. The above analysis should mdicate that the drafters of past legislation have developed considerable sophistication in this area. One only hopes that they will be able to put together a package that is both substantively strong and politically acceptable.

Thomas J. Hutton*

* B.S.F.S. 1978, Georgetown University; third-year student, Boalt Hall School of Law. 